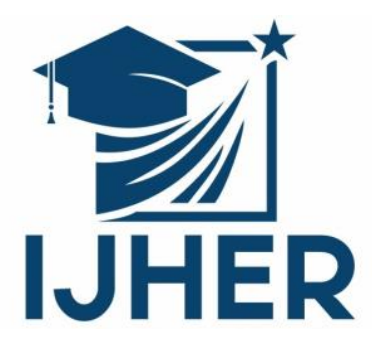

International Journal of Humanities and Educational Research

Volume 2, Issue 4, December 2020, p.19-37

İstanbul / Türkiye

\title{
PROOF GRAMMATICAL RULES IN IMAM AL-NILE \\ APPROACH BY PROPHETIC HADITH
}

http://dx.doi.org/10.47832/2757-5403.4-2.2

\section{MAHMOOD ABDULLAH 1 \\ BASSIDI AL-JAZAERY ${ }^{2}$}

ISSN: $2757-5403$

Article Information

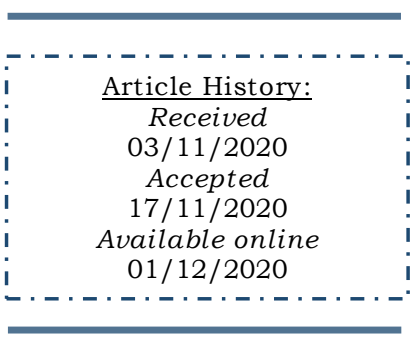

This article has been scanned by iThenticat No plagiarism detected

Copyright $($ C) Published by Rimak Journal, www.rimakjournal.com

Rimar Academy, Fatih, Istanbul, 34093 Turkey All rights reserved

\begin{abstract}
The transcriptionist in that period was a profession practiced by many copyists, and in that profession they had a methodology based on control, mastery, correction and brevity, as well as how to address the errors that occurred to them during the transcription process, and within this approach followed the approach of the coding process; The scribe put a lot of symbols, some of which were related to the abundance of words used in the transcription process, while others were shortened to the names of scholars, and this first part of coding, while the other part of coding was concerned with the method of adjusting, correcting and correcting the transcription process that the copyist adopts regarding If there is a mistake or omission in their view, or if there is an introduction and a delay, or if some words are similar to them.

In our research we tried to explain these symbols and how the scribes dealt with them, while enriching the research with pictures and models for the types of symbols covered in this research, and from God the success.
\end{abstract}

Keywords: Coding, Copying Method, Manuscript Verification.

\footnotetext{
${ }^{1}$ Dr.: Mahmood Fawzi ABDULLAH, Iraqia University, Iraq. mahmood.alkubaisy@gmail.com

${ }^{2}$ A.: Bassidi Abdel Karim AL-JAZAERY, Uqba Bin Nafie Elementary Education Institution, Algeria.
}

\section{IJHER}

International Journal of Humanities and Educational Research

Volume 2, Issue 4, December 2020, p.19-37 


\title{
الترميز عند النساخ وكيفية التعامل معه
}

\author{
3 \\ محمود الكبيسي \\ باسيدي الجزائري
}

\begin{abstract}
ملخص
كانت النساخة في تلك الفترة عبارة عن مهنة يمتهنها الكثير من النََّّاخ، وكان لهم في تلك المهنة منهُج

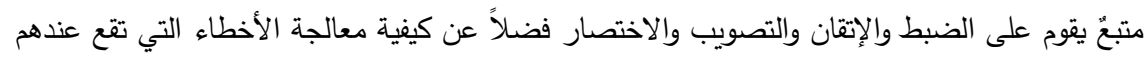

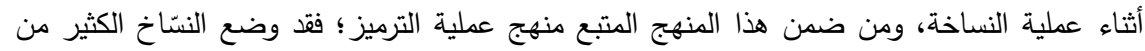

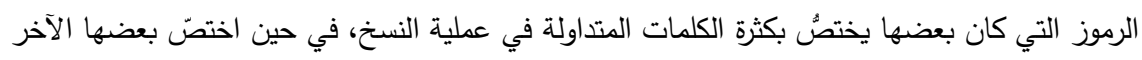

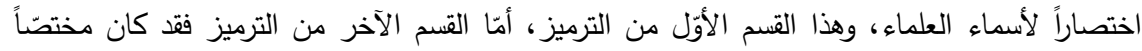

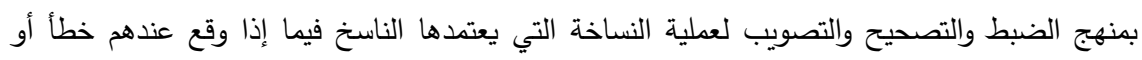

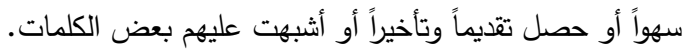

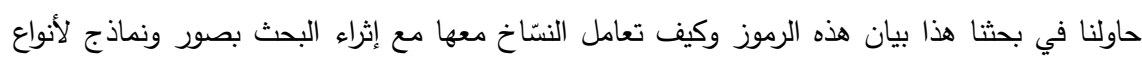
الرموز المتناولة في بحثا هذا، ومن الله التوفيق.

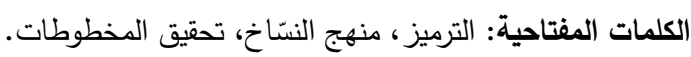

المقدمة

إنّ التداول للدخطوطات من زمن إلى زمن جعلها تحمل بين صفحاتها - زيادة على العلم - ما يسهل فهمها والتعامل معها، فالنساخة وبسبب الظروف الاقتصادية والزمانية عمد العاملون فيها والمؤلفون إلى استعمال الترميز لتسهيل العمل وتيسيره. فالرمز هو اختصار أو شكل وضع للدلالة على مقصود كلام لا يجب إهماله، فزمنهم ليس كمثل زماننا، ولا النساخة عندهم كمثل ما هي عندنا اليوم، فعند التعامل مع المخطوط تدرك الفرق بين النسّاخ قديما والمتمثّل

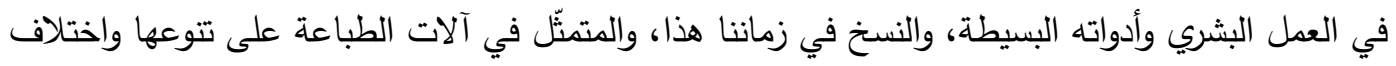

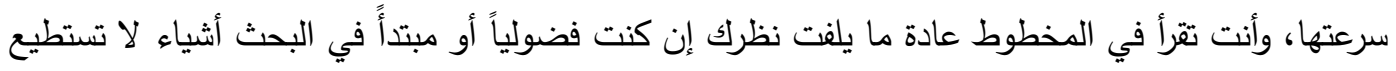

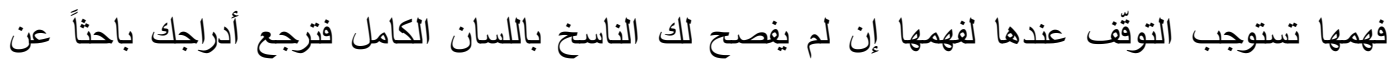
معاني هذه الرموز وما تهدف إليه، وإلا لا محالة أنت آت بالعجب العجاب في تعاملك مع مالم تحسن فهمه باء

3 الدكتور : محمود فوزي عبد الله الكبيسي، كليَّة الآداب، الجامعة العراقية، العراق.

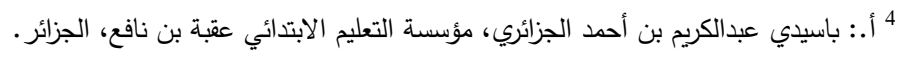

\section{IJHER}

International Journal of Humanities and Educational Research

Volume 2, Issue 4, December 2020, p.19-37 
من الرموز، وحين البحث عنها قد لا تهتدي بداية الأمر إلى مذللٍ لصعابها، ففي حد علمي لم يكن هنالك

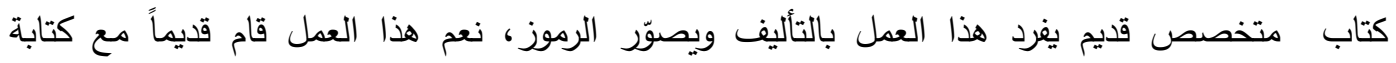
المصحف الشريف وتبلور بشكل خاص عند علماء الحديث، وتوالت السنون حتى أصبحت الظواهر التي تدرس المخطوط علم قائم بذاته، يدرس رموزه وخطوطه ويحلل ألغازه ...إلخ - مع أنّ هناك كتباً في الباب تشرح العمل ولا تصوره، مثل الإلماع للقاضي عياض رحمه الله - ومن بين تلك الظواهر التي تثير الانتباه، ظاهرة استعمال الرموز عند النسّاخ، فما هي الرموز وكيف يجب التعامل معها حين التحقيق، ففي هذا لهاب

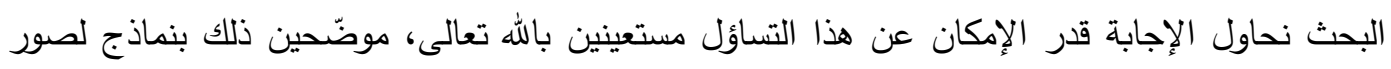
من مخطوطات مختلفة، هذا وإنّا في هذا المقام نتقدم بالثكر الجزيل للثيخ صالح الأزهري فله الفضل وله لهانه اليد الطولى في تعليمنا علم المخطوط، هذا وإنّا لا ندعي العصمة ولا الكمال فيما بحثناه وما توصلنا إليه، ولعل هذا العمل يكون درة من الدرر التي تضاف إلى العقد حتى يصير في غاية الكمال والجمال.

\section{المبحث الأول}

المطلب الأول: عناية المسلمين بالقران والسنة:

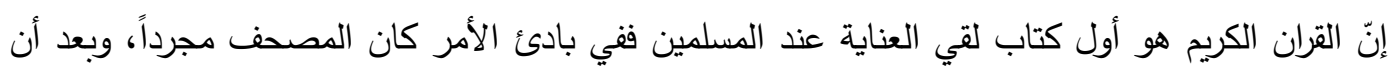
اتسعت رقعة الإسلام ودخول الأعاجم تطرّق اللحن إلى الكتاب العزيز، فهيوا للعناية به بدايةً من أبي الإني

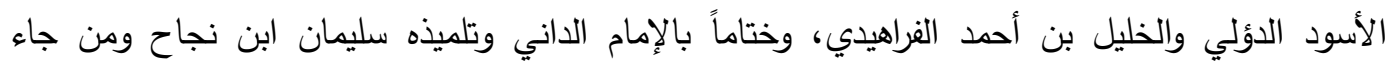
بعدهما، والمنظومات التعليمية التي اعتتت بالرسم والضبط خاصة منظومة مورد الظمآن وذيلها في فني الضبط والرسم، للعلامة سيدي ححمد بن حمح الثريشي الفاسي الشهير بالخراز، وكتاب المقنع للإمام الداني وكتاب أصول الضبط وكيفيته على جهة الاختصار لأبي داود سليمان بن نجاح بن أبي القاسم رحمه الله جميعاً، والأخيرين هما كتابين في الباب، وفي ذلك قال الخراز رحمه الله تعالى، (التونسي،

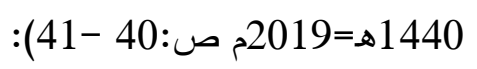

ومالك حظ على الإتباع لفعهم وترك الإبتداع

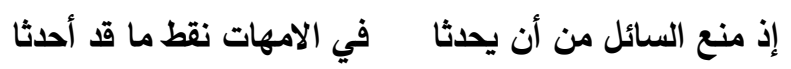

وإنما رآه للصبيان في الصحف والألواح للبيان

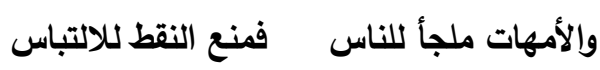

ووضع الناس عليه كتبا كل يبين عنه كيف كتبا

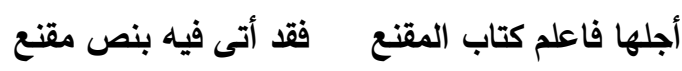

وذكر الثيخ أبو داودا رسما بتنزيل له مزيدا

وقال في الذيل رحمه الله تعالى (التونسي، 1440ه=-2019م ص:40 - 41)، صفحة 338): (دليل

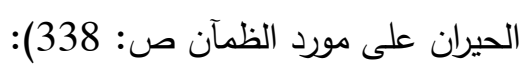

هذا تمام نظم رسم الخط وها أنا أتبعه بالضبط

\section{IJHER}

International Journal of Humanities and Educational Research

Volume 2, Issue 4, December 2020, p.19-37 


\section{كي ما يكون جامعا مفيداً على الذي ألفيته معهوداً

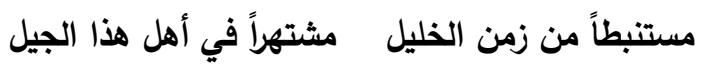

قال أبو داوود سليمان بن نجاح: اعلم أنّ نقط المصاحف هو أقدم من الثنكل وإن كان ذلان فلك معاً مستنبطاً

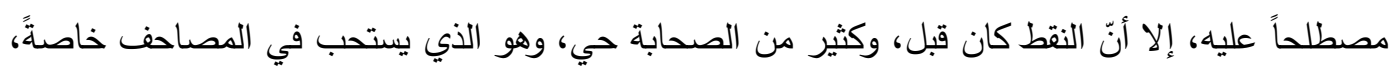

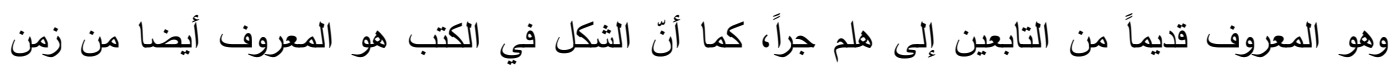

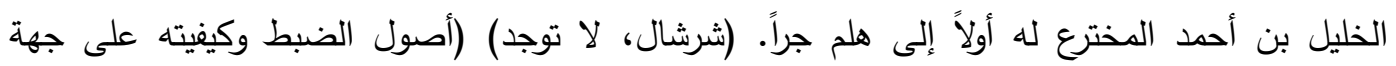

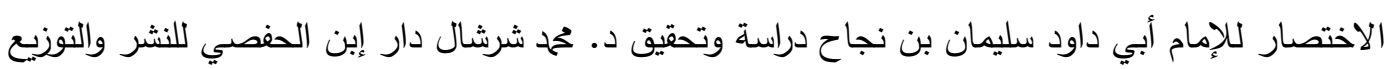

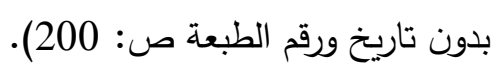
الخدمة والعناية كانت أصلاً لكتاب الله تعالى ثم جر ذلك على العربية عموماً، وأقصد بذلك رموز الضبط

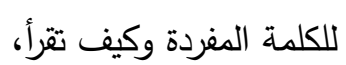
مثلاً قال أبو داوود سليمان بن نجاح: واعلم أنّ التثديد ينقط على وجهين:

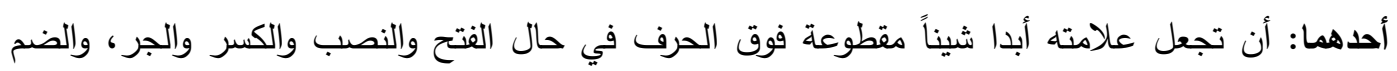

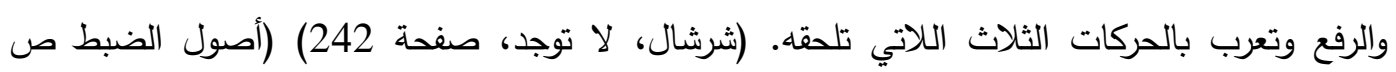

مثال آخر : قال الخرا ز رحمه الله تعالى:

فذارة علامة السكون أعلاه والتثديد حرف الثين

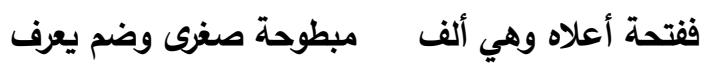

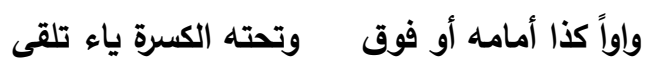

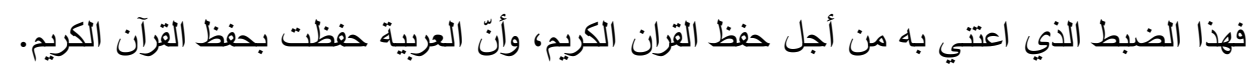

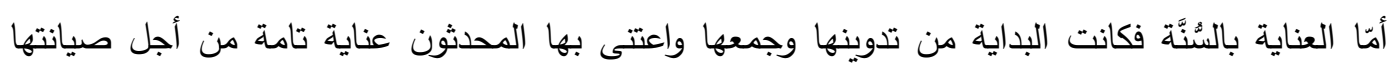
والذود عنها، فقعدوا ونظروا لهذا العلم رواية ودراية.

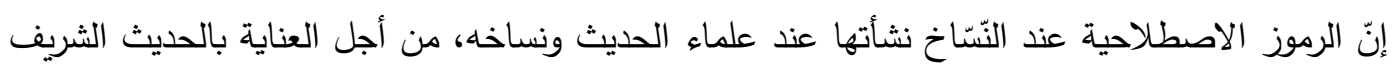
تصنيفاً وسماعاً روايةً ودرايةً، وإليك نموذج مما كتبه العراقي في ألفيته:

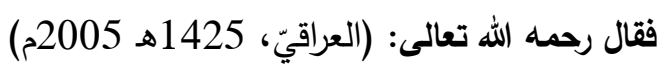

وينبغي إعجام ما يستعجم وشكل ما يثكل لا ما يفهر

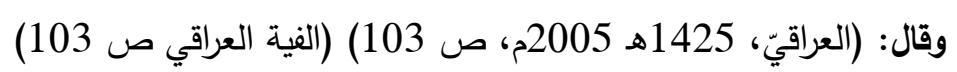

وينقط المهمل لا الحا أسفلا أو كتب ذاكل العرف تحت مثلاً

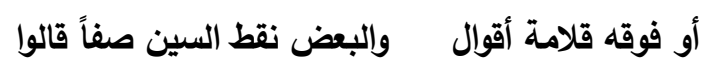

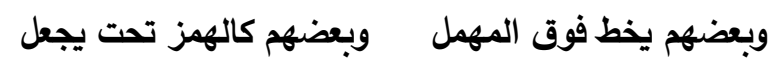

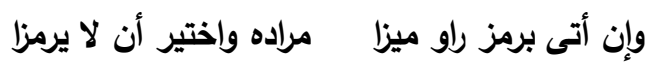

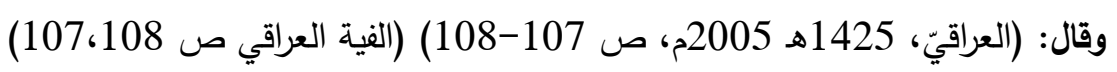

\section{IJHER}

International Journal of Humanities and Educational Research

Volume 2, Issue 4, December 2020, p.19-37 


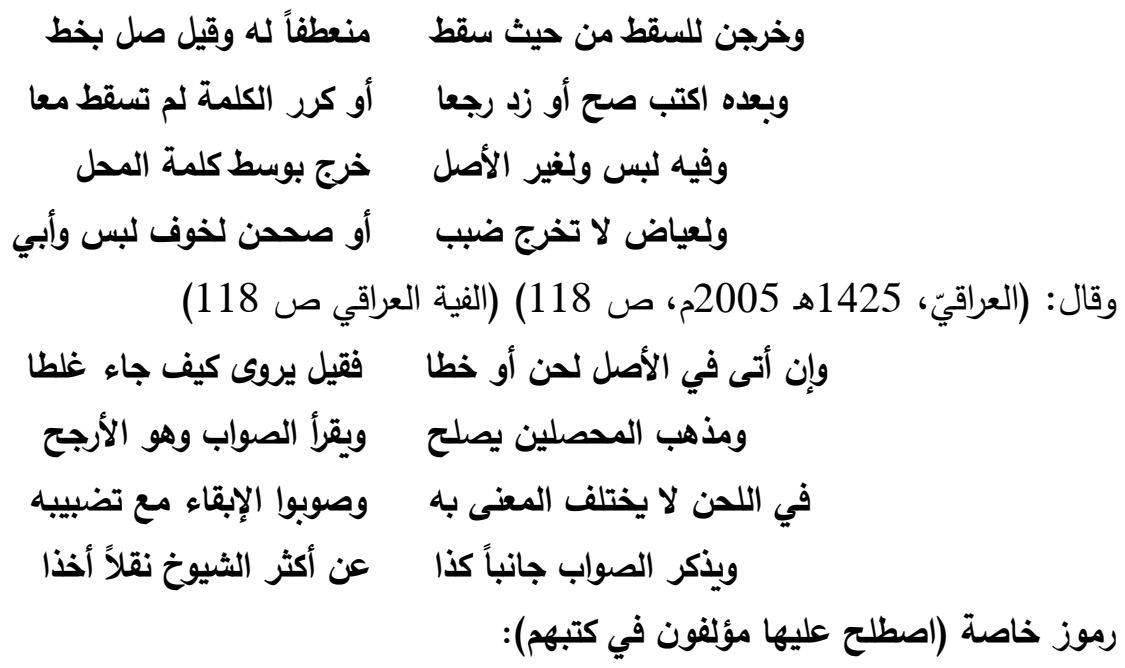

يلجأ المؤلف إلى وضع رموز خاصة في مصنفه لييسر على القارئ التعامل مع الكتاب، من ذلك:

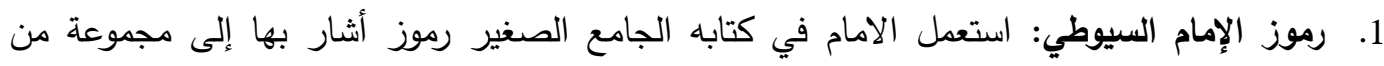

أصحاب المصنفات، وقد نظم هذه الرموز الثيخ يوسف فخر البلبيسي فقال رحمه الله تعالى:

حما لربي مصليا على محمد وآله ومن تلا

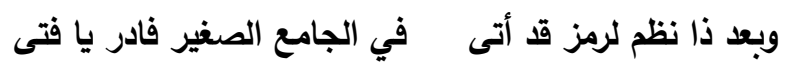

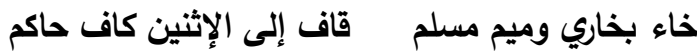

إن كان في مستدرك أطلقه جلالنا وغيره بينه

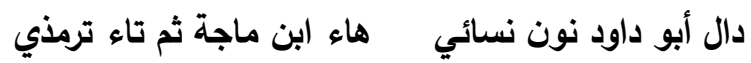

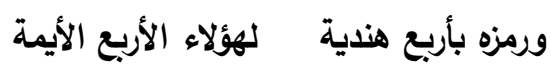

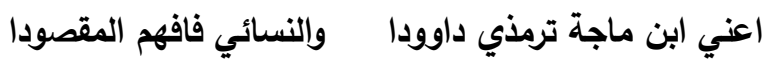

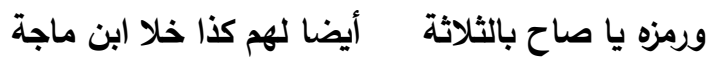

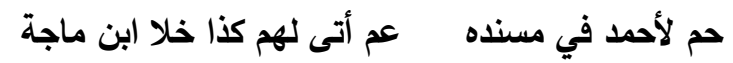

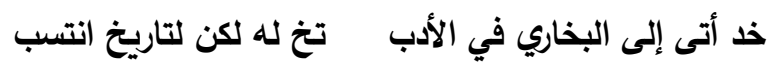

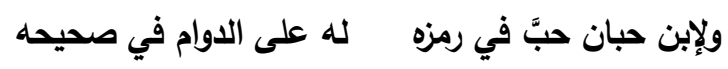

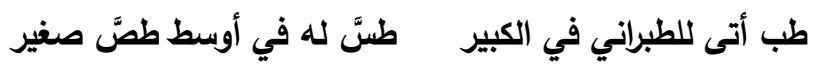

ولإبن منصور سعيد صاد في سنن لله بها يراد

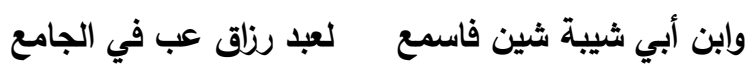

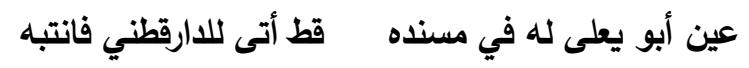

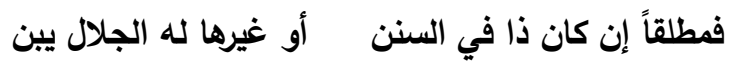

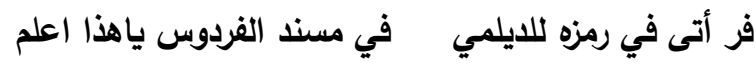

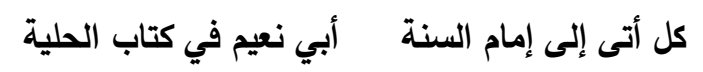

\section{IJHER}

International Journal of Humanities and Educational Research

Volume 2, Issue 4, December 2020, p.19-37 


$$
\begin{aligned}
& \text { هب أتى للبيهقي فأعلمن في شعب الإيمان هق في السنن }
\end{aligned}
$$

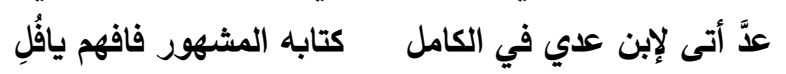

$$
\begin{aligned}
& \text { عق عقيلي جا في الضعفاء خط إلى الخطيب ياذاذا الرائي }
\end{aligned}
$$

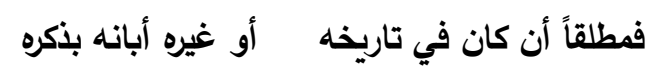

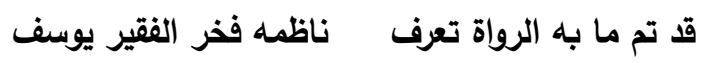

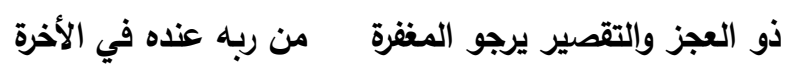

$$
\begin{aligned}
& \text { وأفضل الصلاة والتسليم على النبي المصطفى الكريم }
\end{aligned}
$$

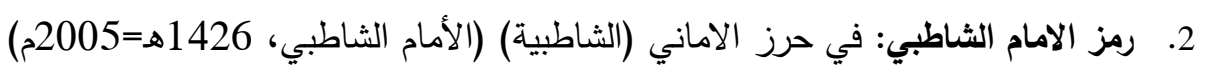

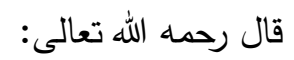

$$
\begin{aligned}
& \text { وها أنا ذا أسعى لعل حروفهم يطوع بها نطم القوافي مسهلاً } \\
& \text { جعلت أبا جاد على كل قارئ دليلاً على المنظوم أول أولاًا }
\end{aligned}
$$

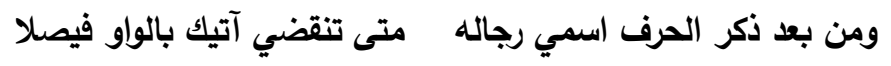

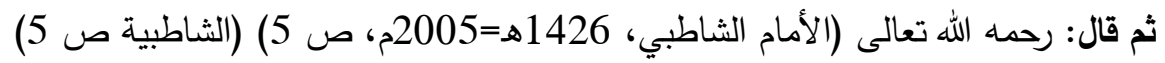

$$
\begin{aligned}
& \text { ومنهن للكوفي ثاء مثلث وستتهم بالخاء ليس بأغفلا }
\end{aligned}
$$

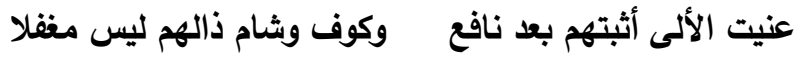

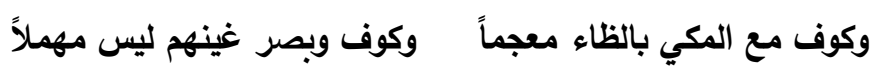

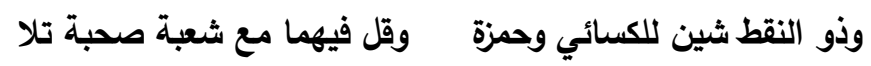

$$
\begin{aligned}
& \text { صحاب هما مع حفصهم عم نافع وشام سما في نافع وفتى العلا }
\end{aligned}
$$

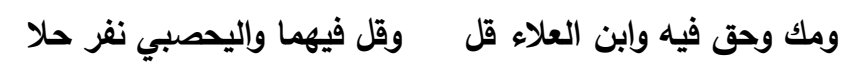

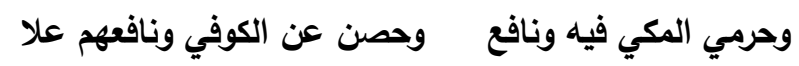

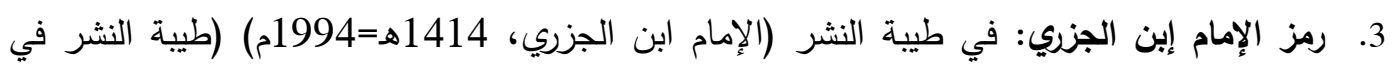

$$
\begin{aligned}
& \text { القراءات العشر للإمام ابن الجزري ضبطه لمحم تميم الزعبي مكتبة دار الهذى المدينة المنورة ط02 سنة الهن }
\end{aligned}
$$

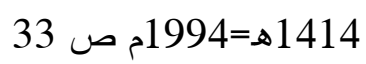

$$
\begin{aligned}
& \text { جعلت رمزهم على الترتيب من نافع كذا إلى يعقوب }
\end{aligned}
$$

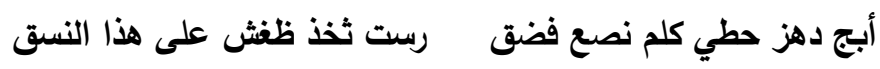

$$
\begin{aligned}
& \text { المطلب الثاني: الحاجة إلى الضبط والإعجام: }
\end{aligned}
$$

\section{IJHER}

International Journal of Humanities and Educational Research

Volume 2, Issue 4, December 2020, p.19-37 
الرسم القرآني لأبي البقاء علي بن عثمان بن محمد بن القاصح تحقيق الثيخ ححم الدسوقي أمين كحيلة دار

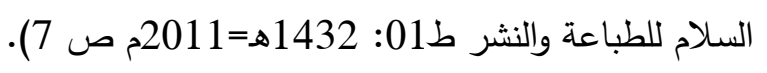

وضبط القرآن من ناحية إعجامه وتثكيله يدخل ضمن حفظ بالكتاب وتسهيل قراءته على الناس.

$$
\text { المبحث الثاني }
$$

المطلب الأول: أنواع الرموز:

طريقة تقسيم الرموز من طرف الباحثين والمنظرين إلى أنواع تختلف كل على حسب اجتهاده ورؤيته وحاجته، وحسب اجتهادنا الخاص قسمنا الرموز إلى قسمين أساسيين، وتحت كل قلى لتم أنواع. القسم الأول: الرموز التي من خلالها يعرف حجم الكتاب وعدد كراريسه أو ملزماته، وهل هو ناقص أو تام. القسم الثاني: الرموز التي تعين على فهم النص المكتوب وقراءته قراءة سليمة وتحت هذا القسم الوفرة الهائلة من الرموز إذ هي الباب في الموضوع وسنتتاولها في المطلب الثاني.

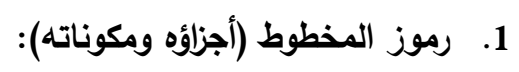

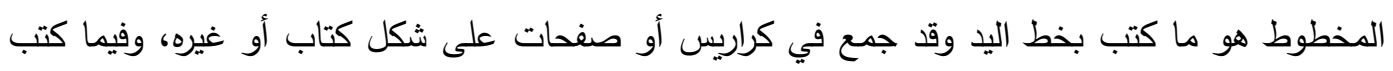

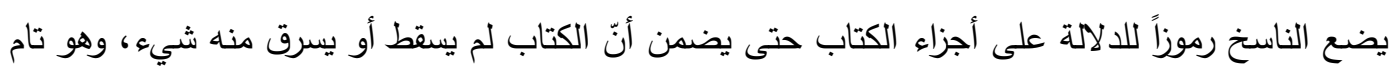

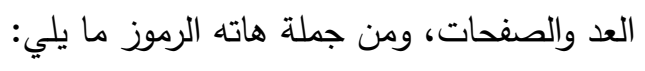
أ. ـ: رمز لكتاب، خاصة في الكتب الكبيرة الحجم لأن المصنَّف يتكون من كتب والكتاب من ابواب والأبواب من فصول، وترمز أيضا إلى كراسة. ب. فه: ترمز إلى الفهرس.

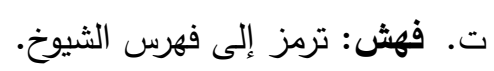

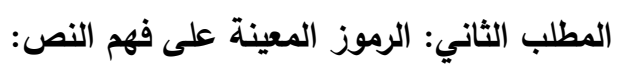

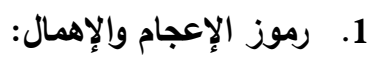

الحروف العربية توصف بأوصاف عدة، حسب المقام الذي تدرس فيه كالوصف بالأبجدية والهجائية والأصلية والفرعية ...وغيرها وعند النساخ توصف توفية بالإعجام والإهمال. الإعجام والإهمال: جاء في القاموس المحيط أعجم فلان الكلام: ذهب به إلى العجمة، والكتاب: نقطه (الفيروزآبادي،

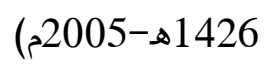
(القاموس المحيط مجد الدين أبو طاهر محمد بن يعقوب الفيروز آبادي تحقيق: مكتب تحقيق التراث في

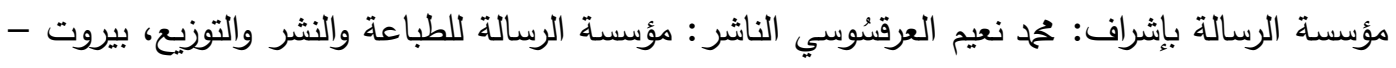

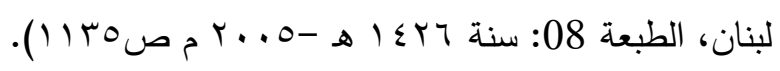

\section{IJHER}

International Journal of Humanities and Educational Research

Volume 2, Issue 4, December 2020, p.19-37 
قال الإمام الداني: أعجمت الكتاب إعجاماً إذا نقطته، وهو معجم وأناله معجم أي: منقوط لتستبين عجمته

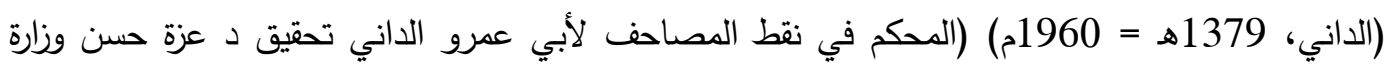

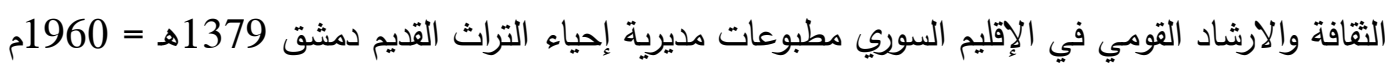
ص 22) (22)

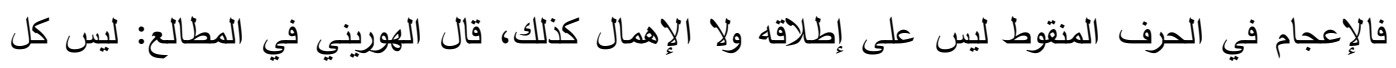

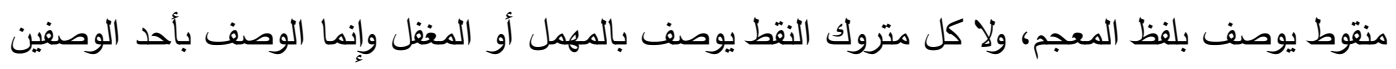

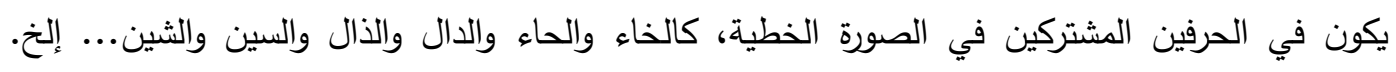

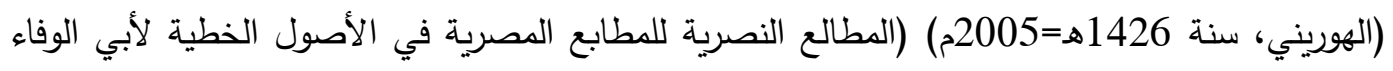

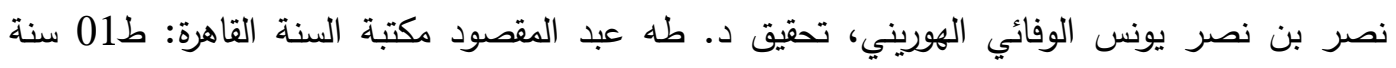

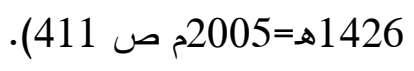

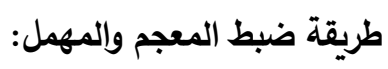

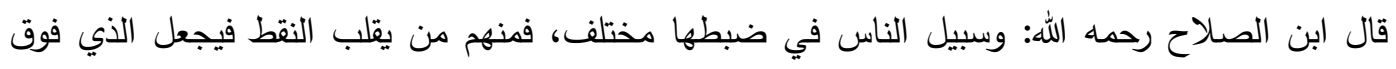

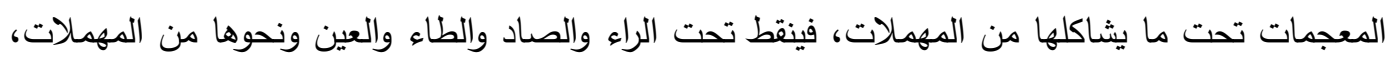

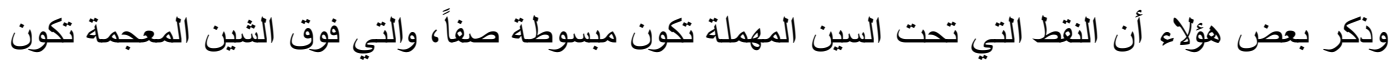

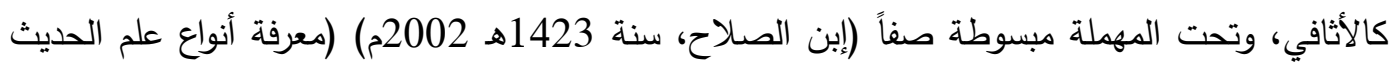

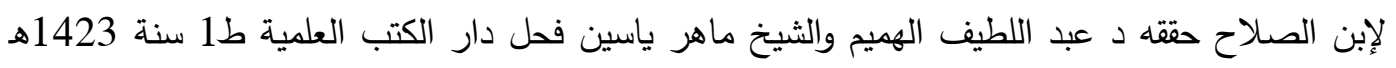
2002 202 ص 297). أ. قلامة الظفر المقلوبة توضع فوق الحرف للالالة على الإهمال.

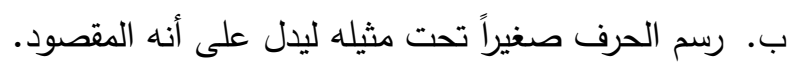
ت. نقط الحروف المشابهة للمعجمة من أسفلها. ث. نقط الحرف من فوقه ومن أعلاه للالالة على أنّ الوجهين صحيحا القراءة. رموز اللحق والاثارة:

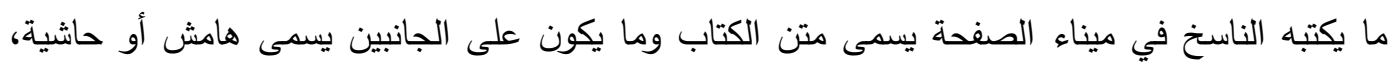

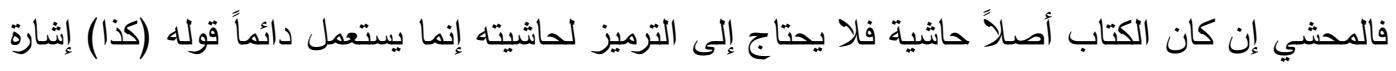

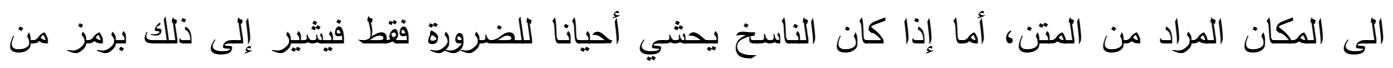

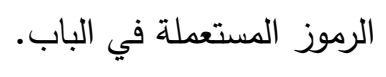

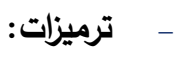
أ. عطفة أو زاوية قائمة أو خط مائل إلى الجهة التي وضع الناسخ فيها الحاشية يميناً أو شمالاً ويسمى

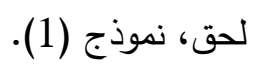

\section{IJHER}

International Journal of Humanities and Educational Research

Volume 2, Issue 4, December 2020, p. 19-37 
ب. رمز على شكل الحرف اللاتيني V وأحيانا فوقه نقطة، وكلما يجب على الباحث التقتيش عن مكان الرمز في الحاشية، نموذج (2).

ت. خط متقطع منحي إلى إحدى جهتي الحاشية. رموز المقابلة والتصحيح:

مقابلة النسخة على الأصل المنقولة منه يعني ضبطها وتصحيح أخطائها، وهي تعد من واجبات النساخة

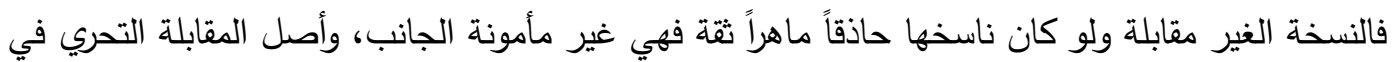
نقل العلوم والأخبار المكتوبة.

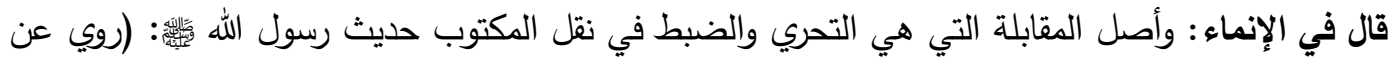

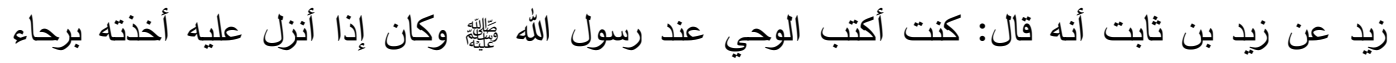
شديدة، وعرق عرقاً مثل الجمان، ثم سري عنه، فكنت أدخل عليه بقطعة القتب أو كسرة، فأكتب وهو يملي

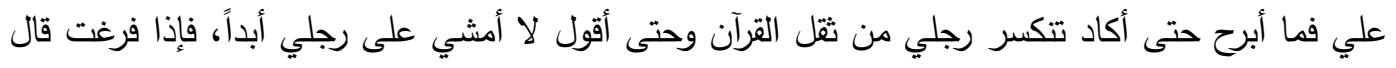
اقرأه فأقرأه، فإن كان فيه سقط أقامه، ثم أخرج به إلى الناس. (النحوي، 1410هـ والتاريخ رواية عبد الله بن جعفر بن درستويه النحوي حققه د أكرم ضياء العمري مكتبة الدار بالمدينة المنورة إنها ط1 1410هـ 377/1) ومما يدلّ على أن المقابلة لها شأن عظيم وهي من الأهمية بمكان، ما أخرجه القاضي عياض في الإلماع

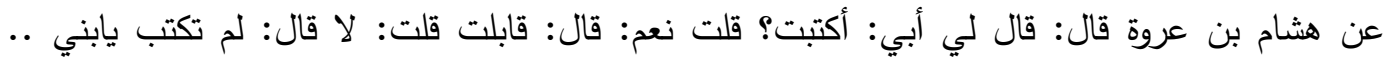
الإلماع وحين المقابلة يحتاج الناسخ إلى تصحيح الخطأ وعليه فسيستعمل رموزاً تبين ذلك، والواجب على الباحث إثبات الصواب وأن لا يشير إلى الخطأ الذي وقع فيه الناسخ.

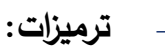
أ. بلغت: ترمز إلى ما بلغت إليه المقابلة أو السماع من الأصل المنقول عنه. (نموذج 05).

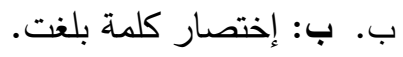

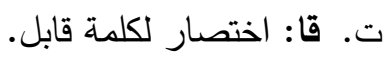

ث. ؟ O الدائرة المغلقة بداخلها خط أو نقطة ترمز إلى المقابلة وعدد النقط فيها بعدد مرات المقابلة. ج. صح أو ص: فوق الكلمة أو الحرف أو الجملة ترمز لصحة ما وضعت علئ عليه. (نموذج 2). ح. كتابة الكلمة المراد تصحيحها بخط سميك أو بحروف مفرقة فوق الكلمة نفسها في الهامش أو بين الأسطر - (1) خ. ب: أو بيان: رمزان للدلالة على ما أبهم في المتن.

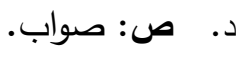

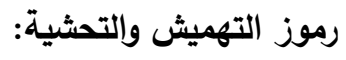

\section{IJHER}

International Journal of Humanities and Educational Research

Volume 2, Issue 4, December 2020, p.19-37 


$$
\text { الحاشية جمع حاشيات وحواشي (الحاشية من كل شيء جانبه وطرفه). }
$$

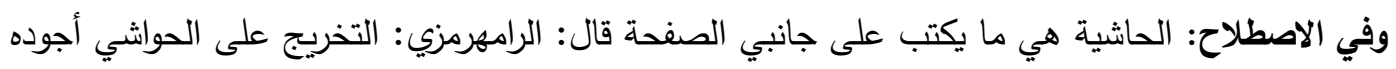

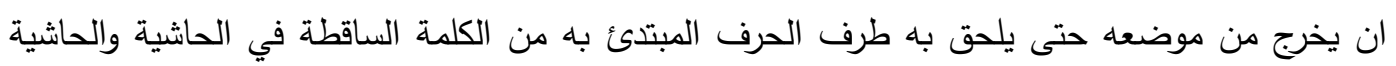

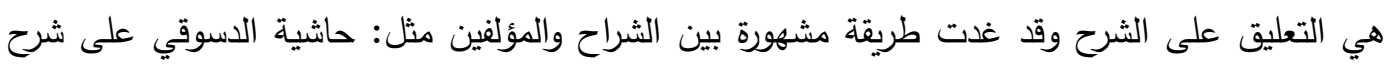

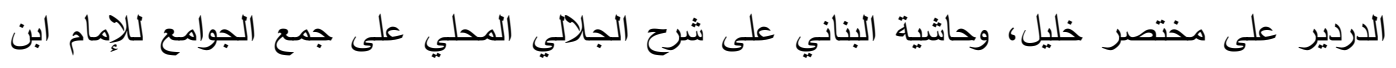

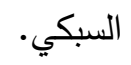
أ. حش أو ح أو ح: ترمز إلى الحاشية.

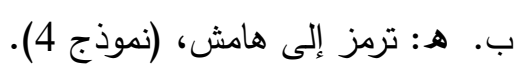

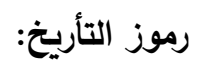

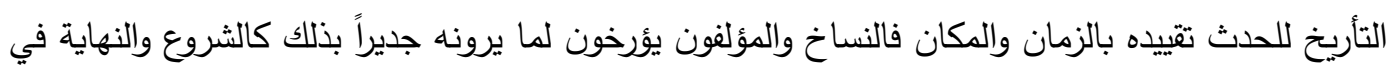

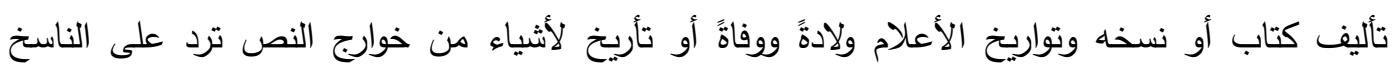
فيسجلها. ومما درج عليه النساخ استعمال حساب الجمل في التأريخ وله طريقتان طريقة المشارقة وطريقة المغاربة مثال على ذلك قول ابن غازي مقيداً وفات ابن مالك رحمه اللها

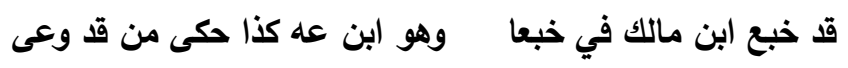

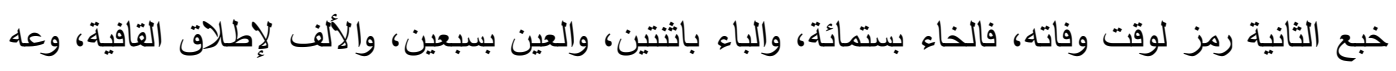

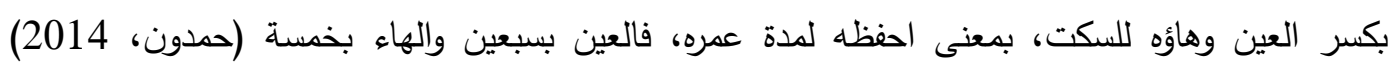

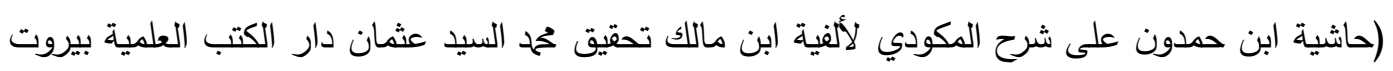

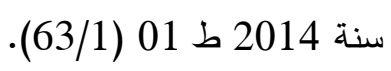
أمّا التأريخ بالأعداد فتارة باللسان وتارة بالأرقام وتارة بالكسر مثال: قال ابن بري في الدرر اللوامع:

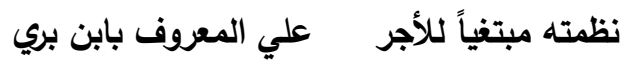

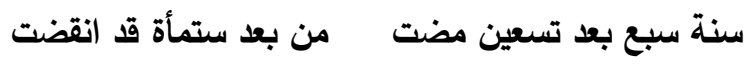

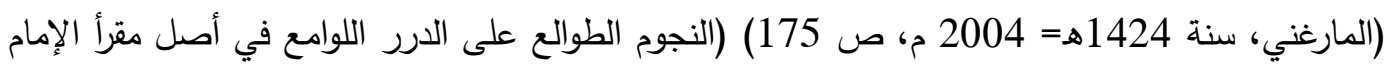

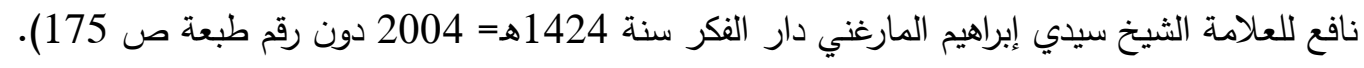

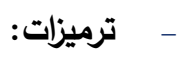

الأرقام التي درج عليها النساخ المغاربة هي من هذا القبيل: 4.3.2.1. والمشارقة درجوا على استعمال

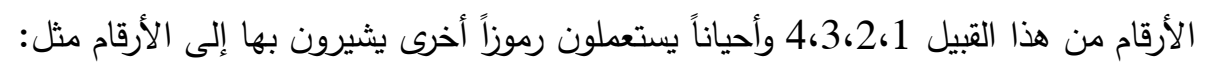
نماذج: (نموذج 7).

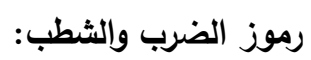

\section{IJHER}

International Journal of Humanities and Educational Research

Volume 2, Issue 4, December 2020, p.19-37 
الخطأ وارد على كل إنسان حتى على الحذاق من كل فن، فحينما يقع الناسخ في الخطأ يقوم بعدة إجراءات

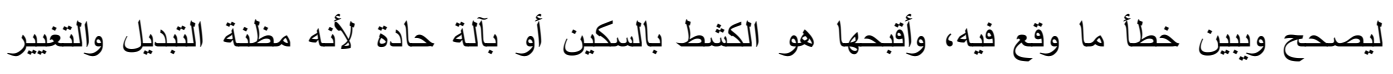
وأسهلها اللعق باللسان للخطأ حتى يختفي قال القاضي عياض في في الإلماع: سمعت شيخنا أبا بحر سفيان بن العاصي الأسدي يحكي عن بعض شيوخه أنه كان يقول: كان الثيوخ يكرهون حضور السكين مجلس الإنس

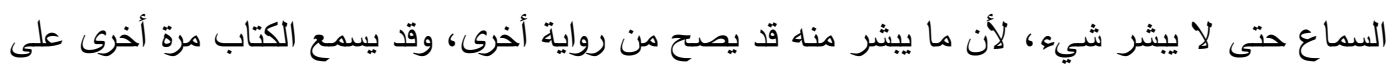

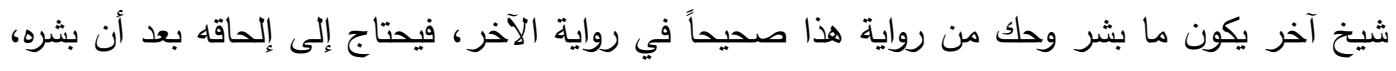

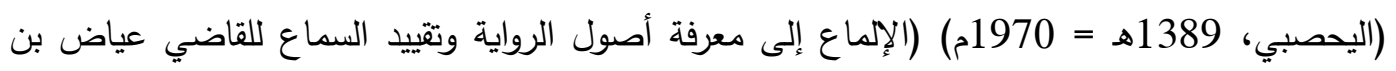
موسى اليحصبي تحقيق السيد أحمد صقر ط01 سنة 1389هـ = 1970م دار التراث القاهرة والدكتبة العتيقة تونس ص 246) وأغرب شيء استعمله النساخ هو اللعق باللسان: قال القاضي عياض: حدثنا

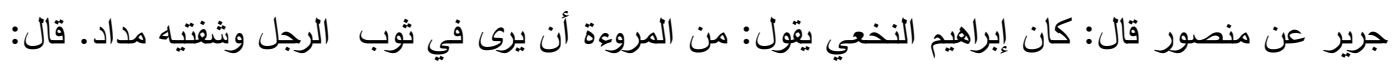

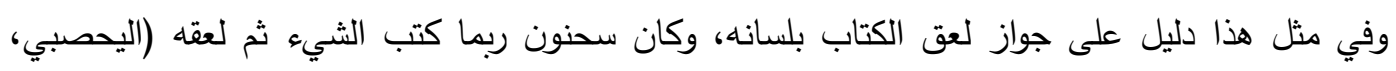

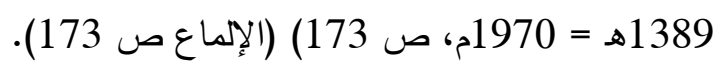
قال ابن الصلاح: ويتتوع طرق المحو يعني: فتارة يكون بالأصبع أو بخرقة، قال من أغربها مع أنه أسلمها

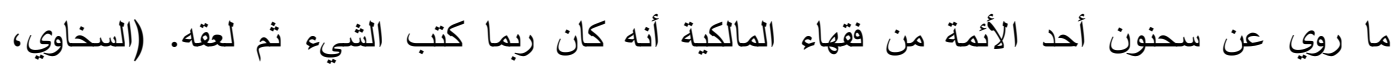

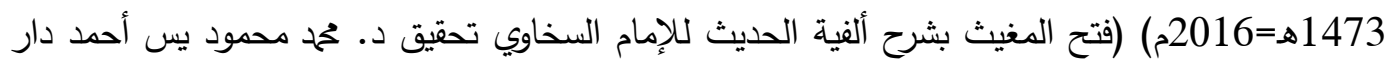
ابن الجوزي القاهرة ط01 سنة 1473هـ=2016م 956/2) كما أن الناسخ قد يلجأ إلى الضرب على دمثلى الكلام

$$
\text { أو التضبيب عليه فما هي الضبة. }
$$

الضبة:

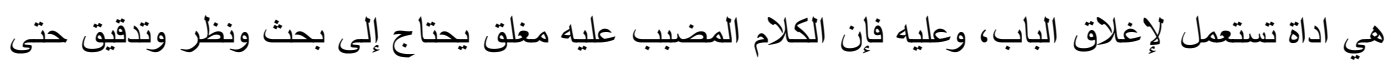

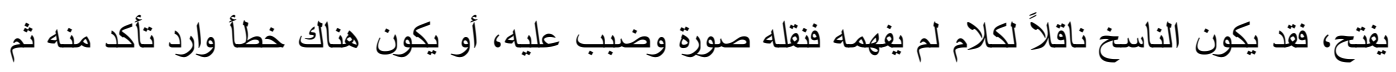
نقله وضبب عليه، مثل المعلومة المغلوطة أو خطأ نحوي وله وجه من الصحة حتى إذا تأكد مما ضبيه صحح عليه.

أ. الضرب بوضع خط على الكلام مختلط به أو غير مختلط به، بدايته لا ونهايته إلى، أو من إلى. ب. الشطب بالطمس. ت. تحويق بقوسين الأول في البداية الكلام والثاني في نهايته. ث. التحويق بعارضة رأسها الأول في البداية والثاني في النهاية. ج. التحويق بحيز مغلق على الكلام الخاطئ.

\section{IJHER}


ح. الضرب على الحرف الثاني إذا تكرر الحرف خطأً (اليحصبي، 1389هـ = 1970م، ص 172) (الإلماع 172 وقال: وأرى أنا إن كان الحرف تكرر في أول سطر مرتين أن يضرب على الثاني لئلا يطمس أول السطر ويسخم... إلخ يقصد رحمه الله سلامة اوائل السطور). خ. خ: اختصار كلمة خطأ. د. ض: ترمز إلى الضبة أي: الكلام الذي لم يتبين له فيه وجه صواب أو شك فيه. رموز اختصار الكلمات:

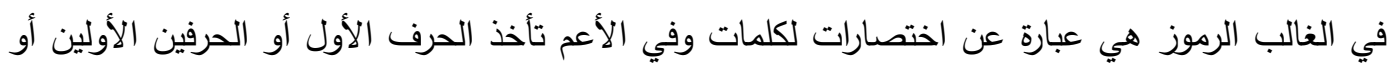

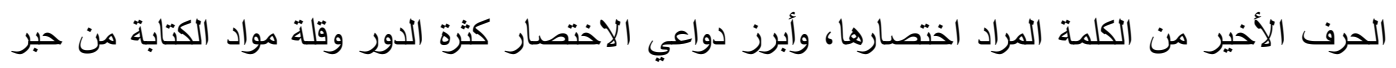
وورق. -

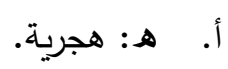

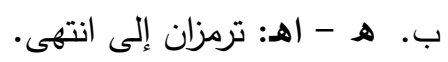
ت. ح: حينئذ. ث. ظ: ظاهر. ج. مخ: مخطوط. ح. نا: ناسخ.

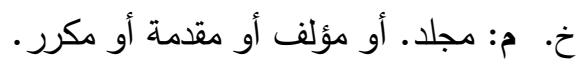

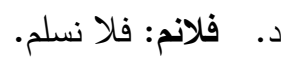
ذ. ـ كقه: كقوله. ر. البط: الباطل. ز. تع: تعالى. س. بط: باطل. ش. رض: رضي الله عنه. ص. إنش: إن شاء الله. رصن الله رموز مختلفة الأبواب: 1. رفَّ: ترمز للدلالة على أن الحرف لا يقراً مشدداً. 2. 0 0. 3. .... خط متقطع للدلالة على وجود بياض.

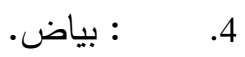


المطلب الثالث: كيفية التعامل مع الرموز:

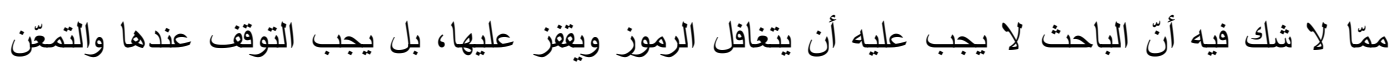

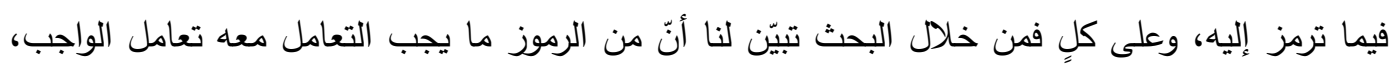

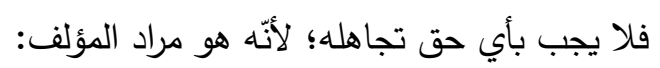

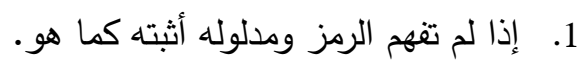

2. رموز التصحيح والضرب لا تتبت بل يثبت ما رمزت إليه إذا كان صواب وان كان خطأ فقد كفاك هون

$$
\text { 3. ر روز الترقيم بالحساب المغربي أو المشرقي تتبت كما هي. }
$$

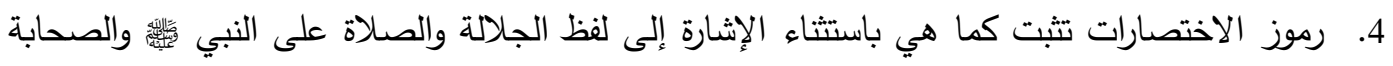

$$
\text { 5. ر رموز التحديث ورموز الأعلام تثبت كما هي. }
$$

6. التضبيب يجب التعامل معه بتحقيق ما ضبب علئ عليه الناسخ.

النتـــــــ

1. الرموز في الغالب هي اختصار لكلمة كثيرة الدور في الكتاب أو اختصار لجملة تأخذ حروف رمزها من حروف بداية أو نهاية الكلمة.

2. التعامل الباحث مع الرموز يجب أن يكون بقدر عال من الاعتناء والاحترافية، فقد يكون حلُّ الرمز

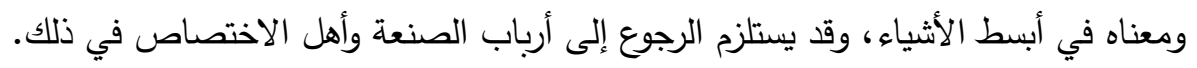

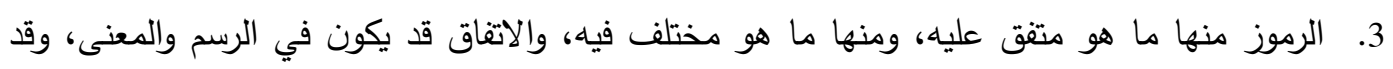
يختلف في إحداهما. التــوصـيـات: 1. نقترح أن يكون هناك لجنة أو موقع ومركز تحت إشراف أساتذة وشيوخ متخصّصين في المخطوطات والتحقيق متفرغين للعمل، تتابع أعمال المحقين المشاركين وترشدهم، وتذلل لهم الصعاب، وفئ وفي الأخير يطبع العمل حتى لا يبقى حبيس الرفوف مثل الكثير من الرسائل المحقّقة وغيرها.

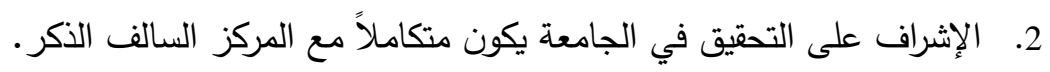

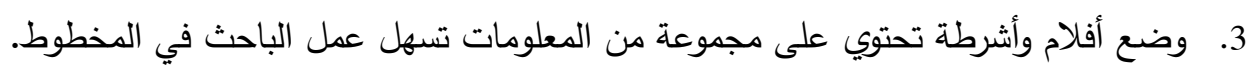

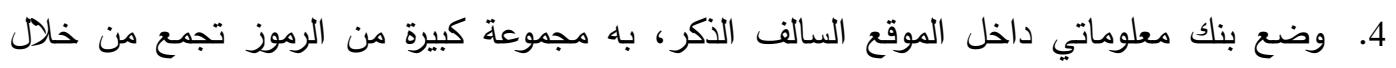

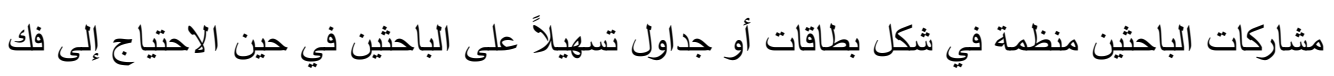
رمز لم يفهمه أو أي معلومة في مجال التحقيق والمخطوط.

\section{IJHER}

International Journal of Humanities and Educational Research

Volume 2, Issue 4, December 2020, p.19-37 
5. طبع كتاب مصور به كل رموز المخطوط أو غالبها في جميع العلوم

صور النماذج المشار إليها في المتن

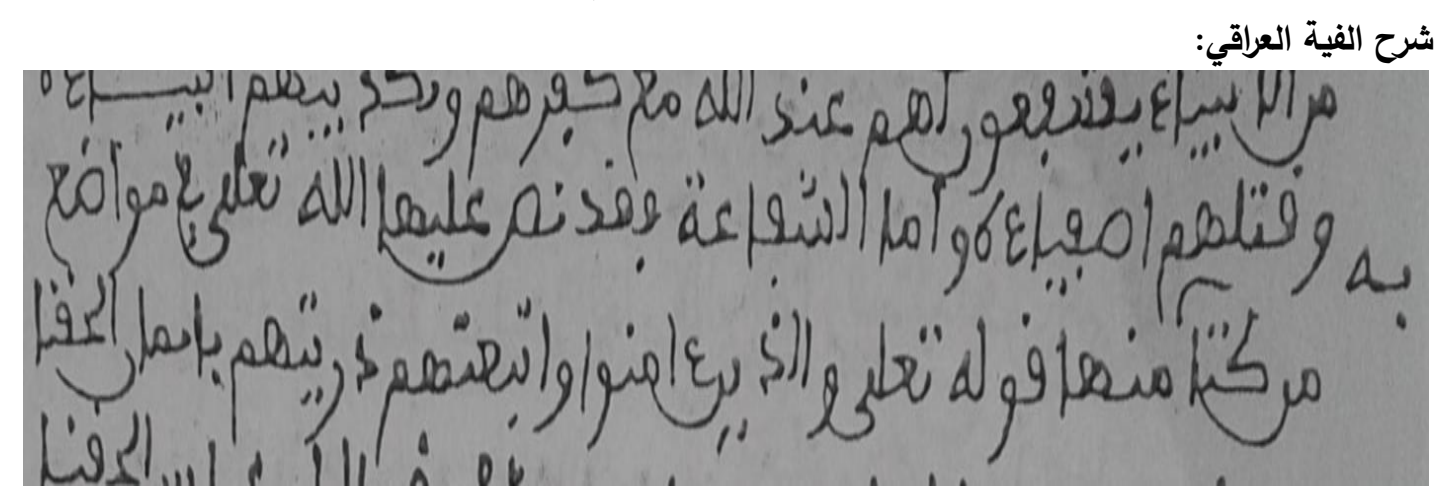

نموذج رقم (1) - ن

لوحة من القراءان الكريم اخر سورة الانثقاق واول سورة البروج:

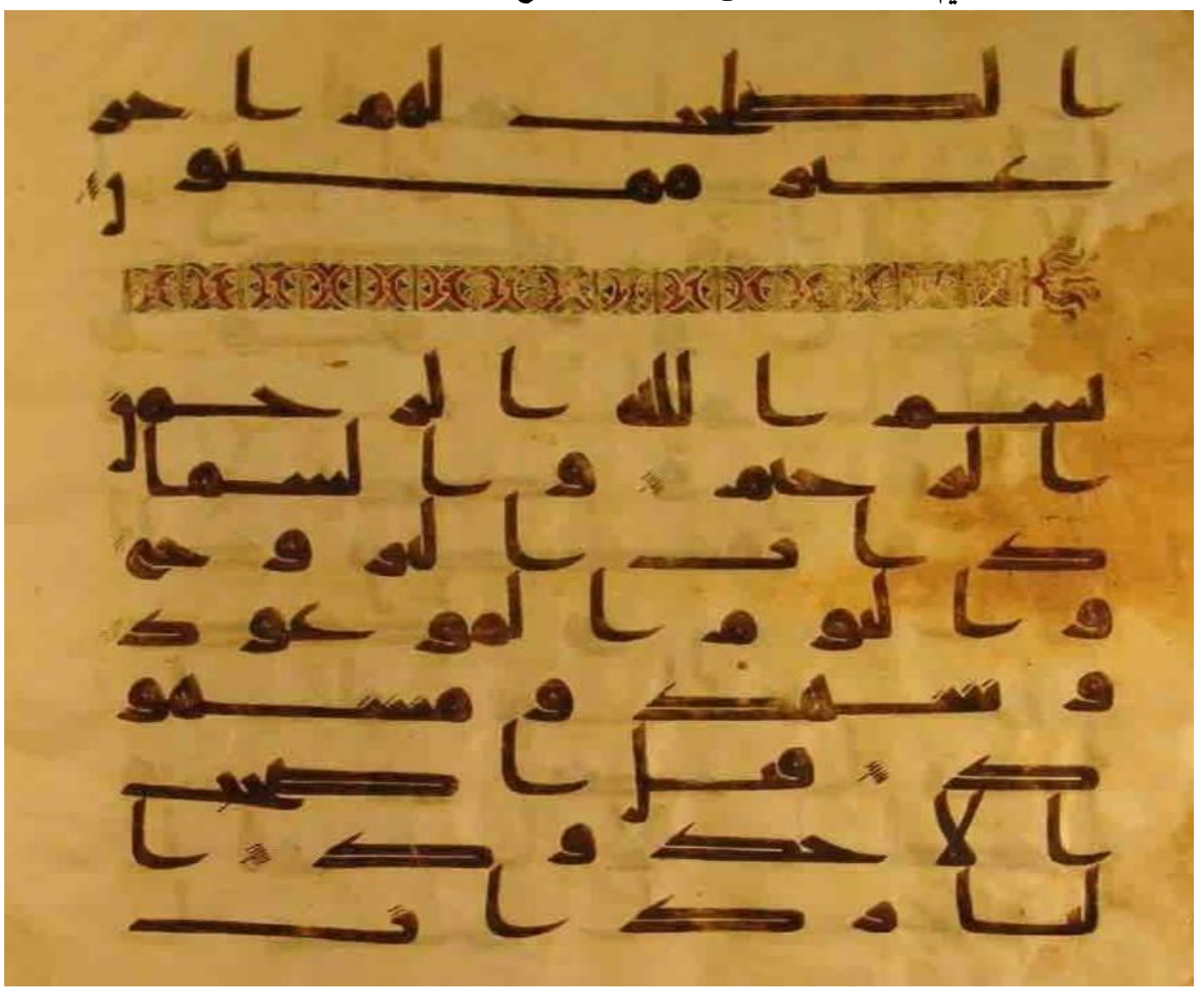

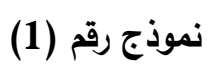

رمز صح زبدة الاسرار شرخ مختصر المنار اللوحة 13:

\section{IJHER}

International Journal of Humanities and Educational Research

Volume 2, Issue 4, December 2020, p.19-37 


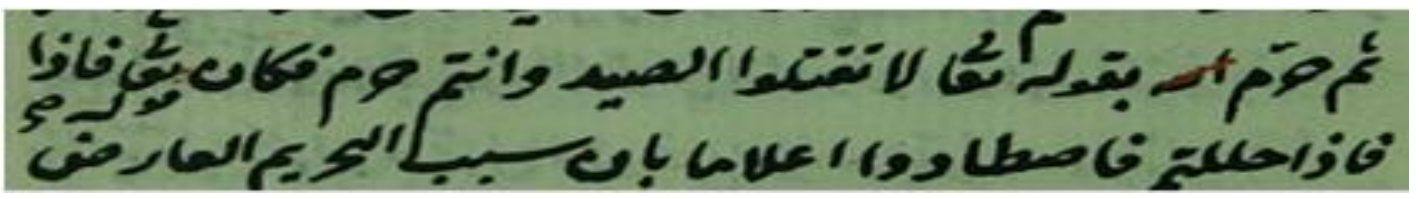

نموذج رقم (2)

زبدة الاسرار شرح مختصر المنار اللوحة 13:

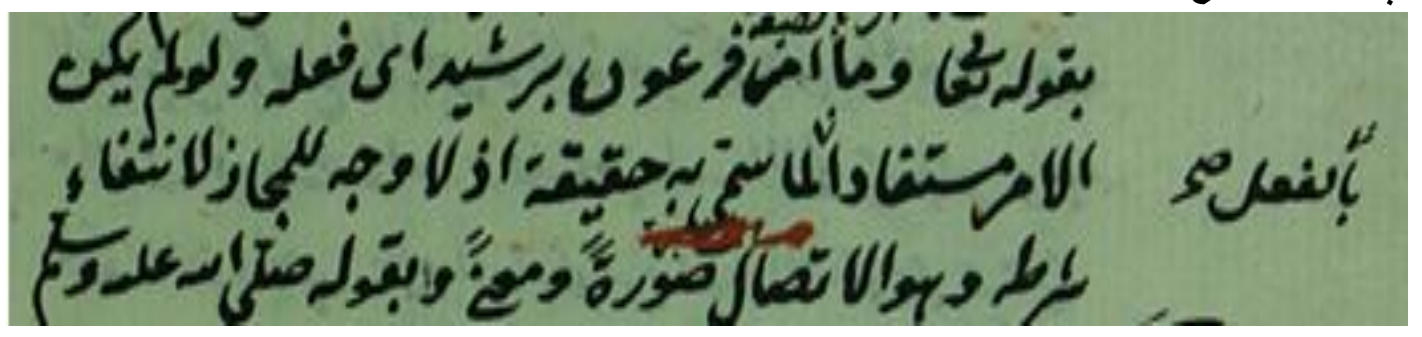

نموذج رقم (2)

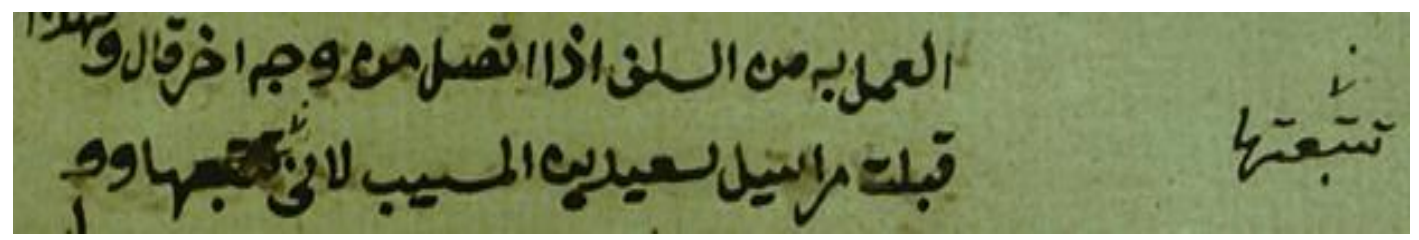

نموذج رقم (2)

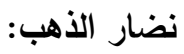

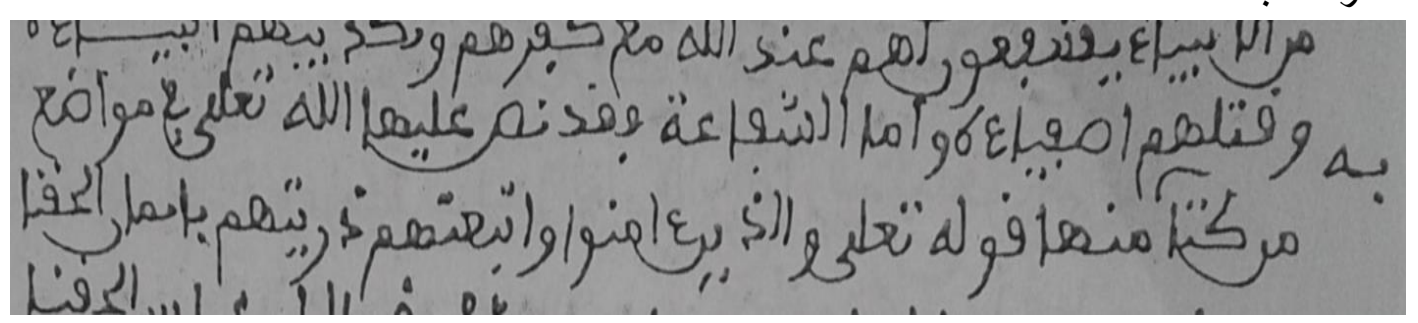

نموذج رقم (3) - 2) - ن

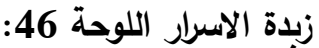

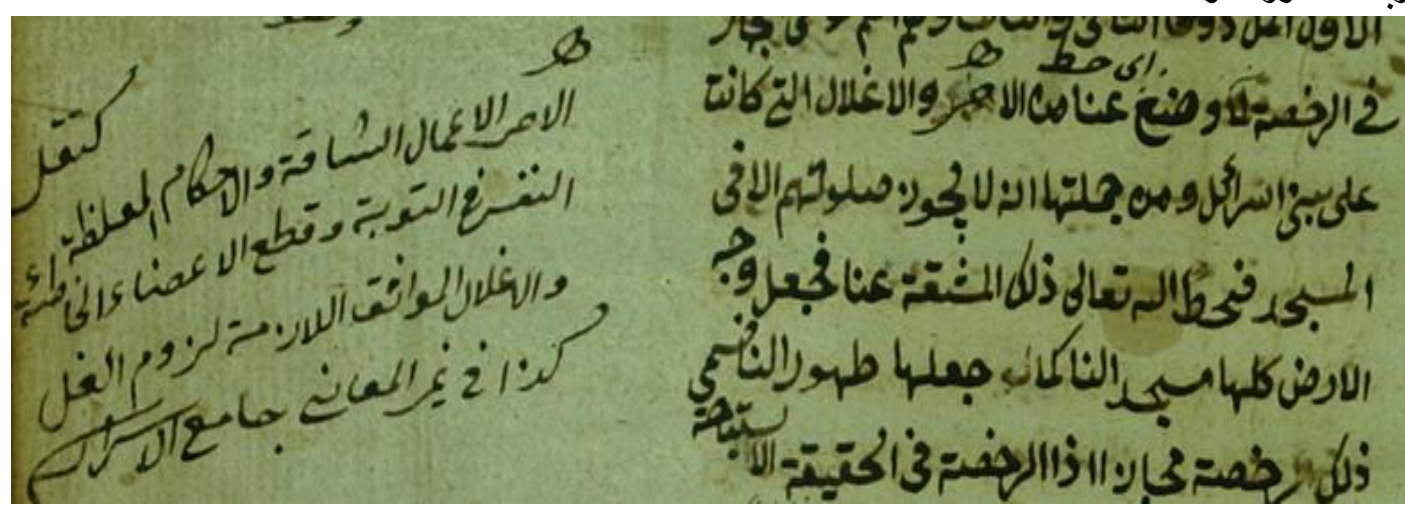

نموذج رقم (4) - ن

\section{IJHER}

International Journal of Humanities and Educational Research

Volume 2, Issue 4, December 2020, p.19-37 


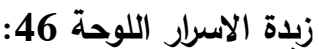

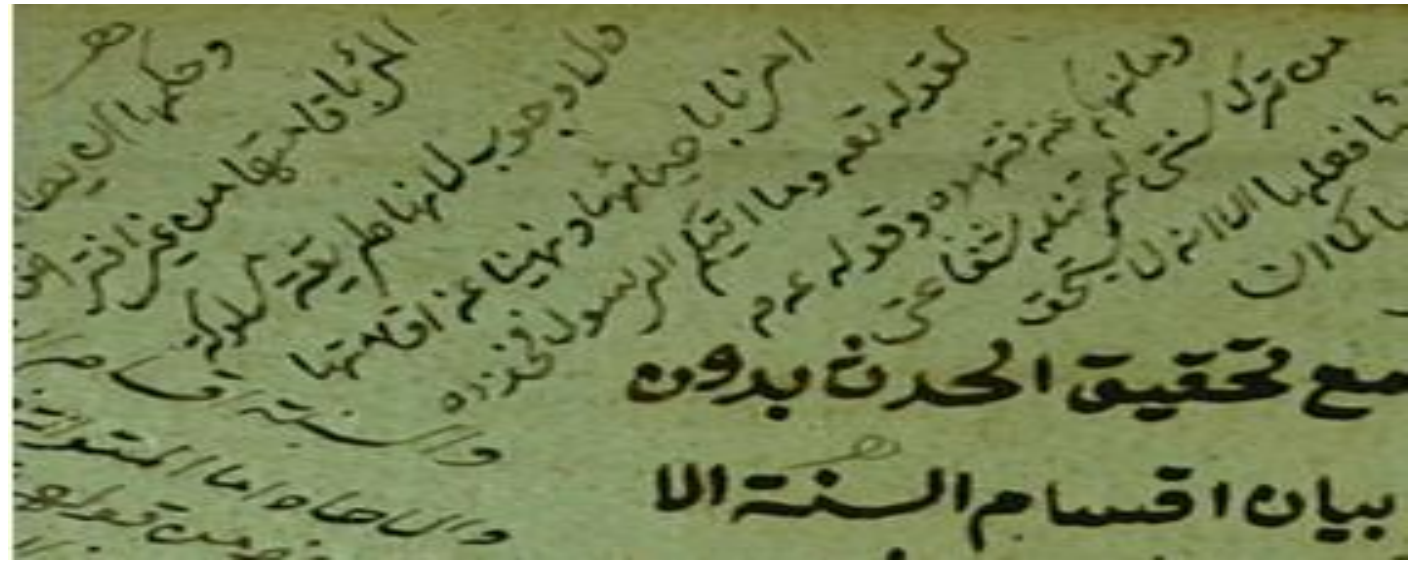

نموذج رقم (4)

شرح الفية العراقي:

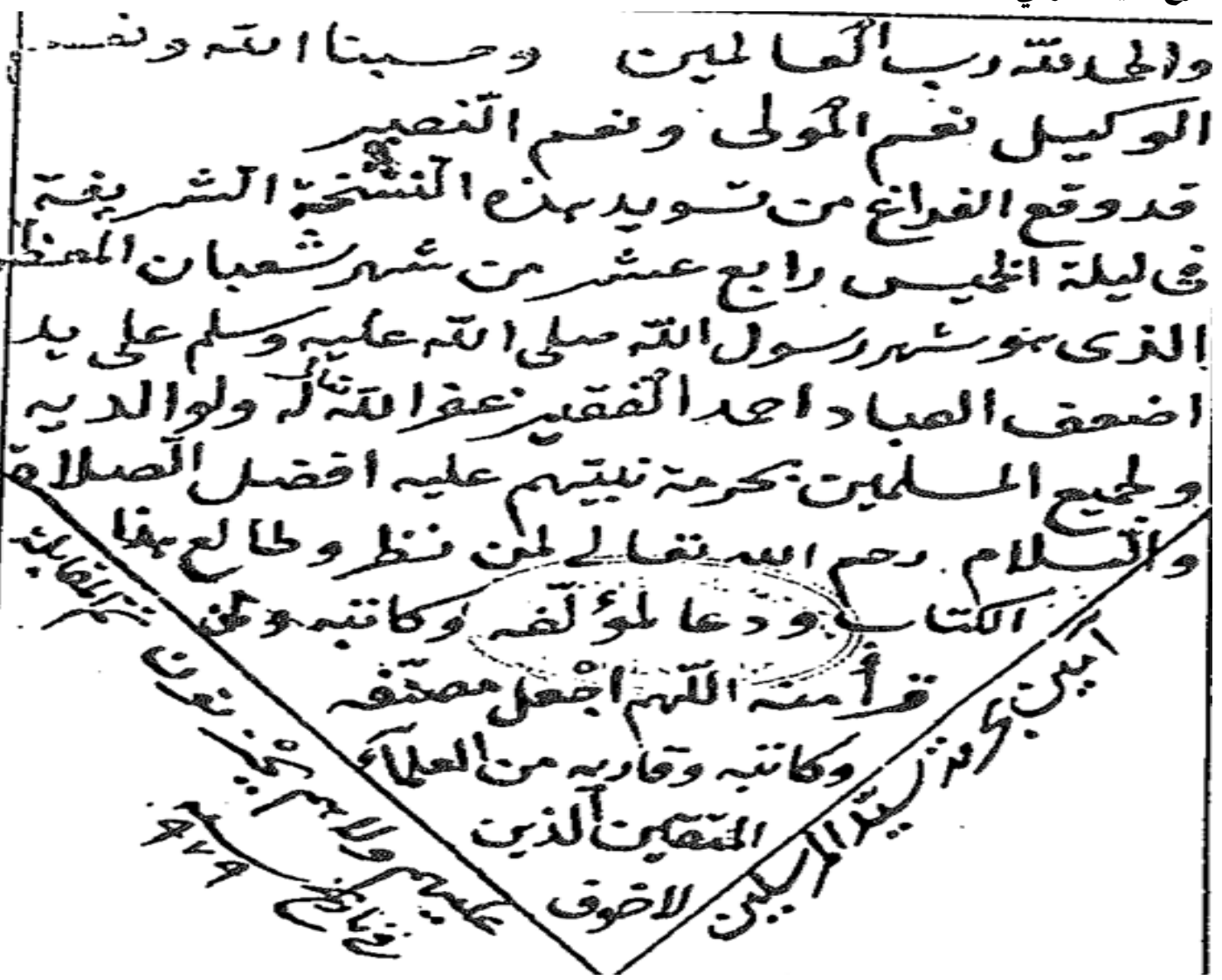

نموذج رقم (5)

شرح مثلث قطرب للفيروزبادي:

\author{
IJHER
}

International Journal of Humanities and Educational Research

Volume 2, Issue 4, December 2020, p.19-37 


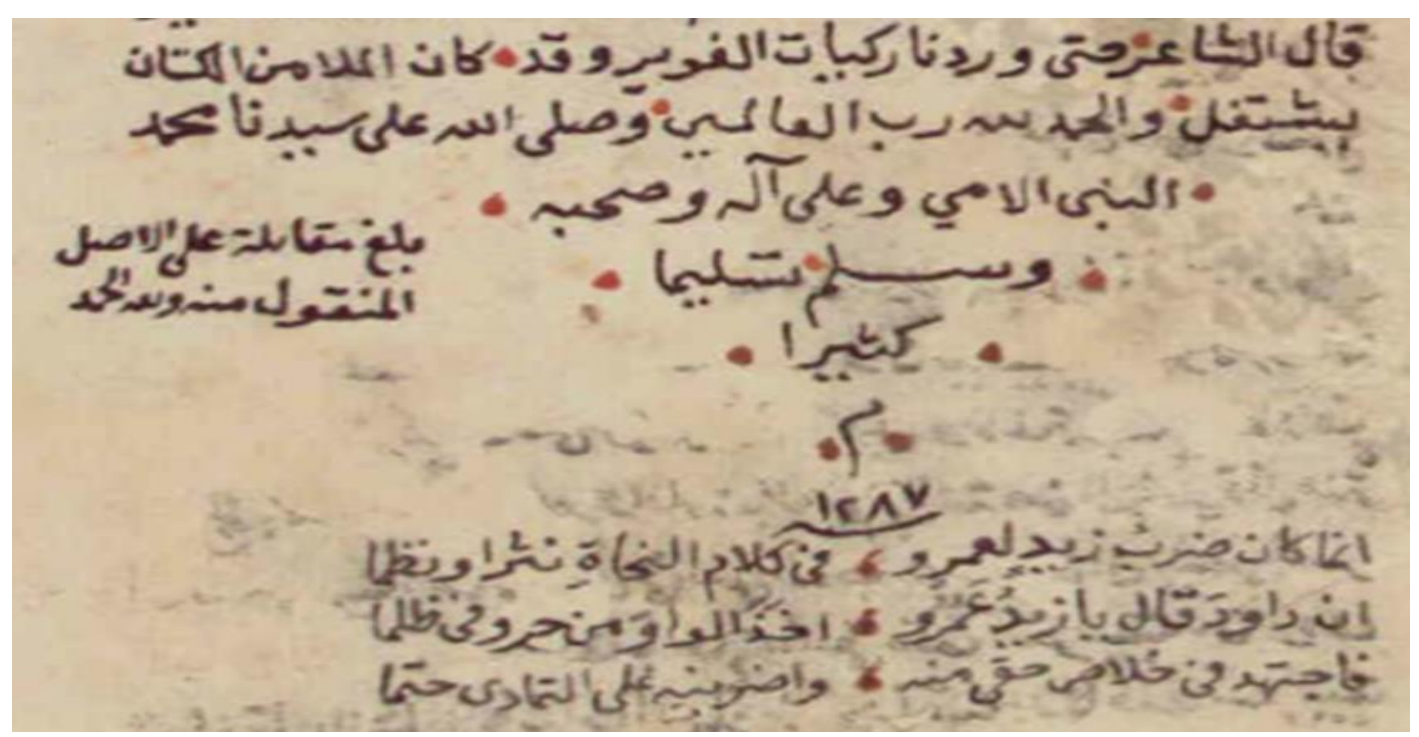

نموذج رقم (5) - (5)

رمز المقابلة الكاشف:

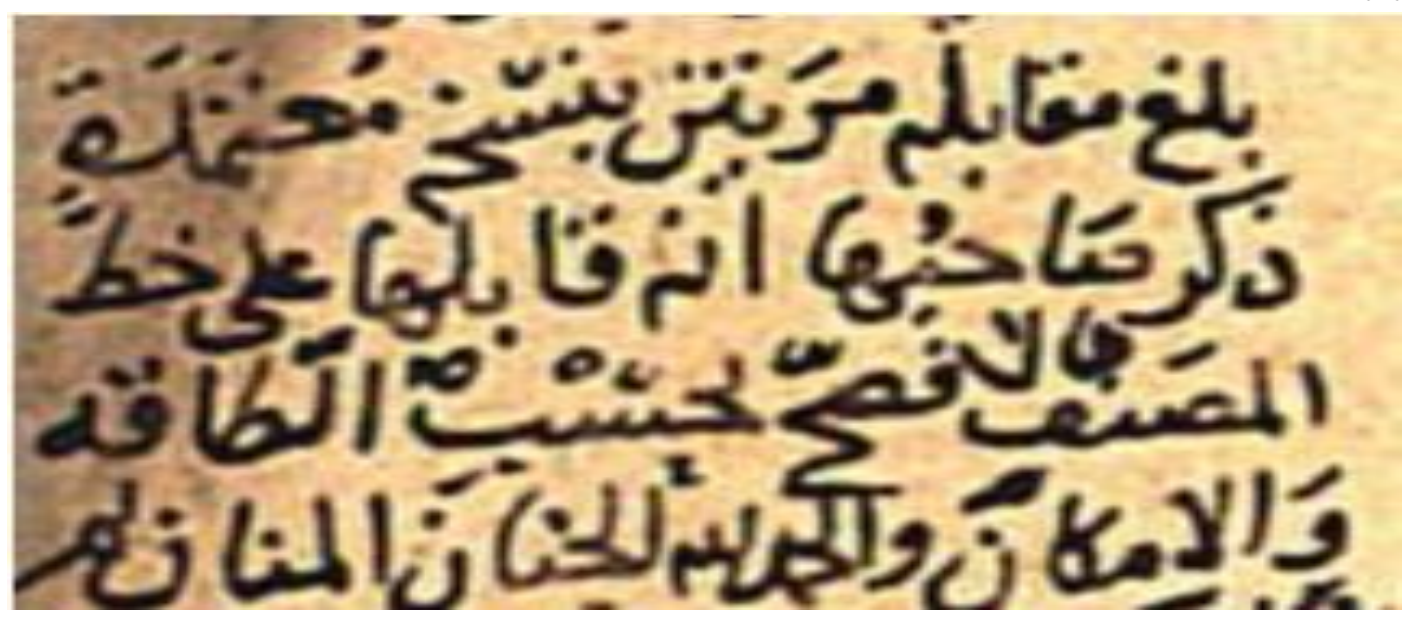

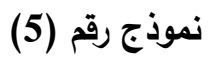

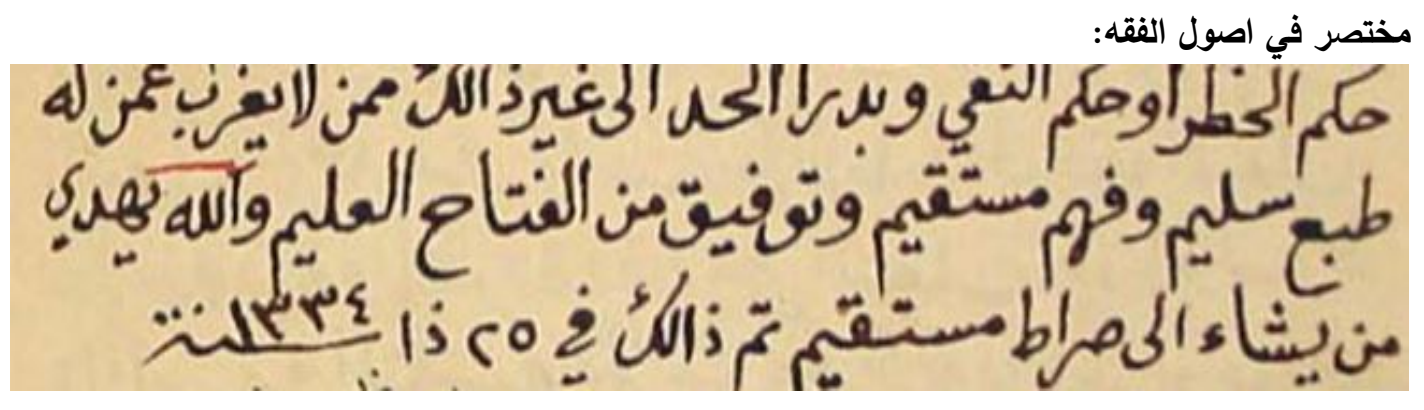

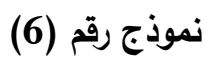

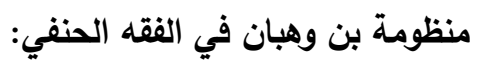

\section{IJHER}

International Journal of Humanities and Educational Research

Volume 2, Issue 4, December 2020, p.19-37 


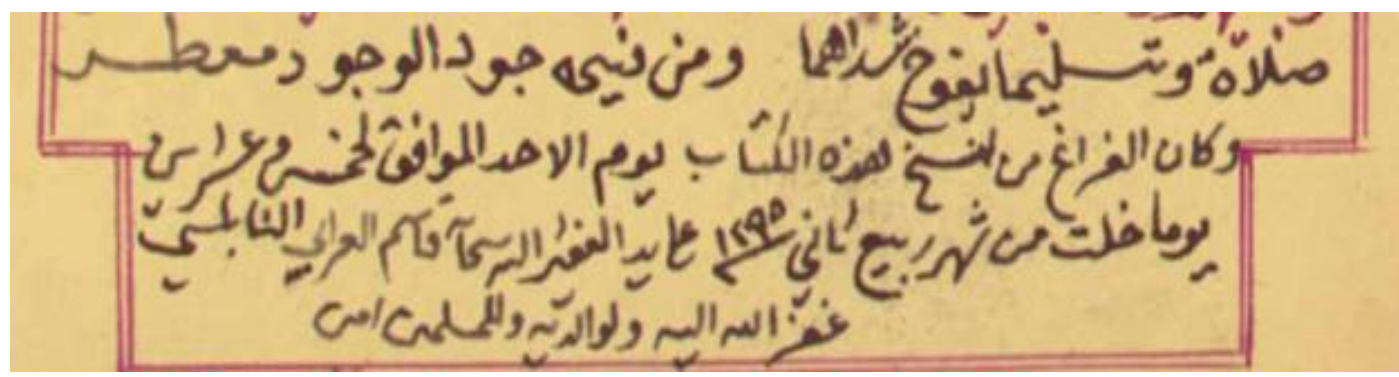

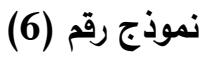

رمز الى الرقم اربعة وهو يثبه حرف العين الكاشف في معرفة من له رواية في الكتب الستة للإمام الذهبي:

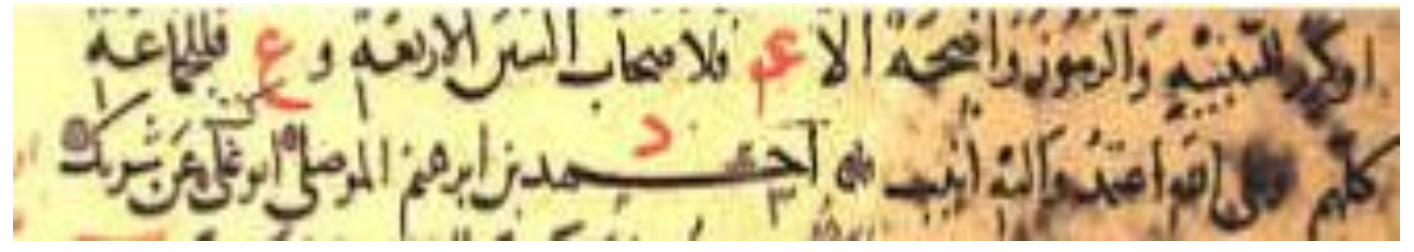

نموذج رقم (7)

رموز الارقام: الرقم 5 يثبه حرف B:

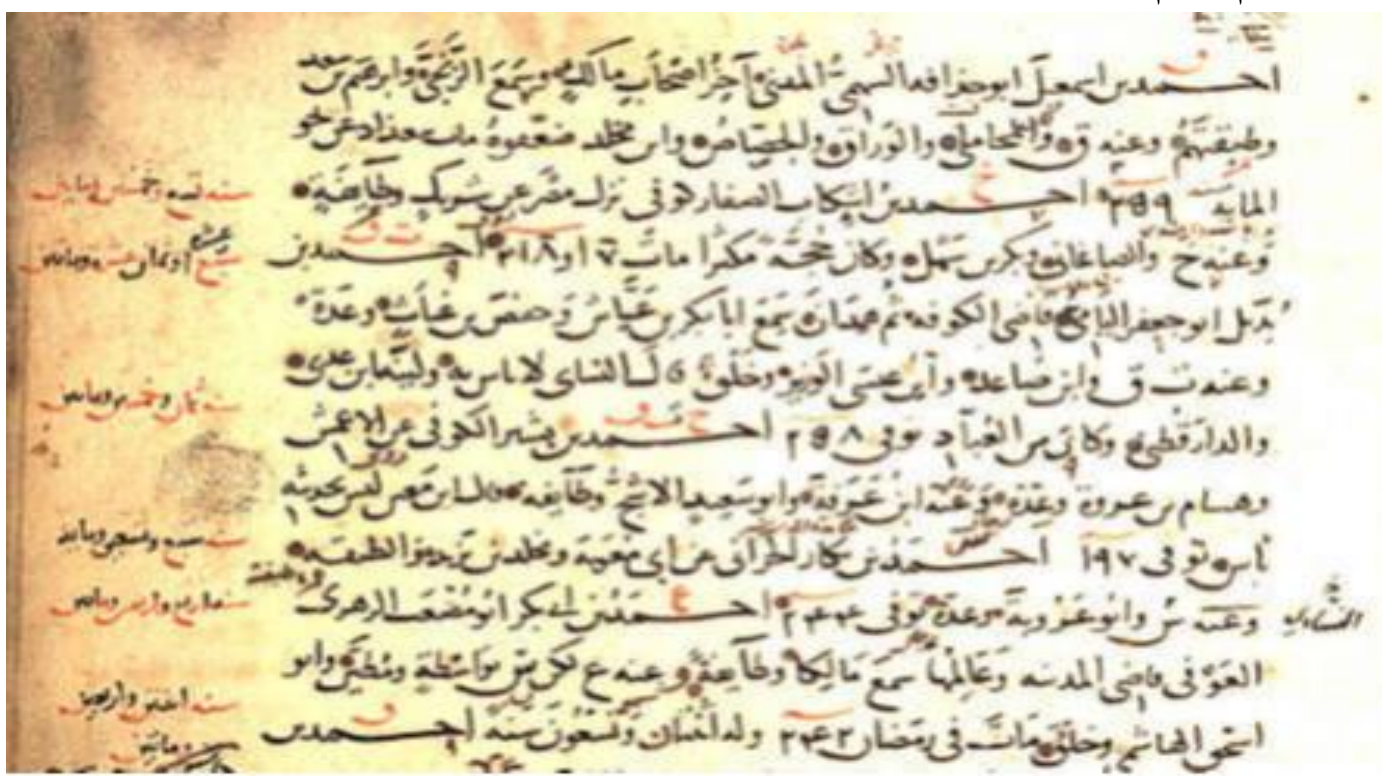

نموذج رقم (7)

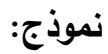

\section{IJHER}

International Journal of Humanities and Educational Research

Volume 2, Issue 4, December 2020, p.19-37 


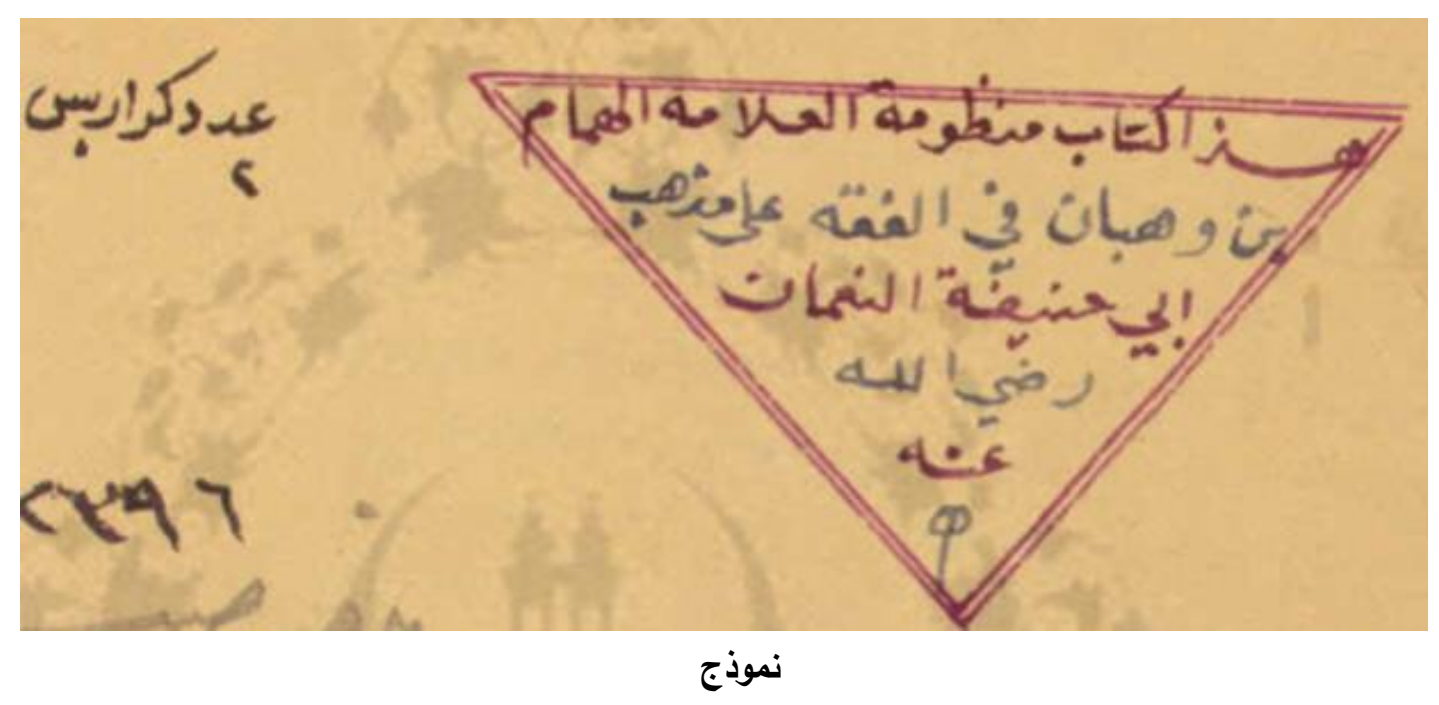

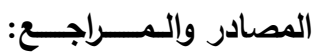

1. إبن الصلاح. (سنة 1423هـ 2002م). معرفة أنواع علم الحديث حققه د عبد اللطيف الهميم والثيخ ماهر ياسين فحل (المجلد 01). بيروت: دار الكتب العلمية. 2. ابن حمدون. (2014). حاشية ابن حمدون على شرح المكودي لألفية ابن مالك تحقيق تحمد السيد عثمان (المجلد (01) · بيروت: دار الكتب العلمية.

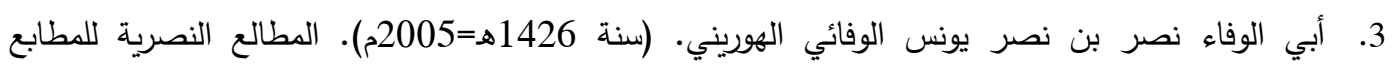
المصرية في الأصول الخطية تحقيق د. طه عبد المقصود (المجلد 01). القاهرة: مكتبة السنة. 4. الإمام ابن الجزري. (1414هـ=1994م). (طيبة النشر في القراءات العشر ضبطه محمد تميم الزعبي (المجلد 02). المدينة المنورة: مكتبة دار الهدى. 5. الإمام أبي داود سليمان بن نجاح دراسة وتحقيق د. محم شرشال. (لا توجد). أصول الضبط وكيفيته على جهة

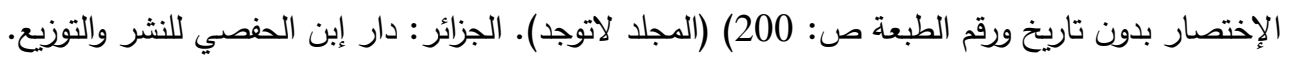

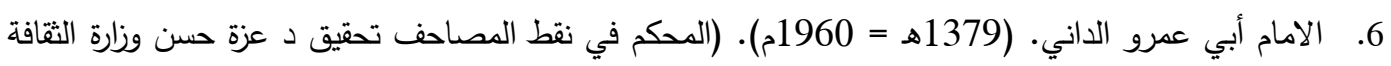
والارشاد القومي في الإقليم السوري. دمشق: مطبوعات مديرية إحياء التراث القديم.

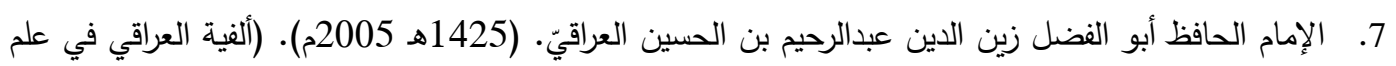
الحديث (المجلد ط01). مصر والجزائر : دار المستقبل ودار الامام مالك. الإن.

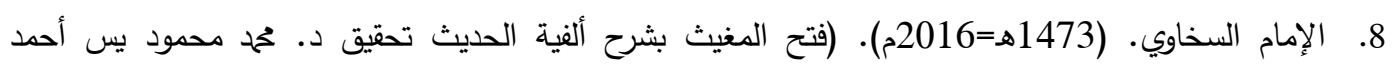
(المجلد 01). القاهرة: دار ابن الجوزي. (الإمان. 9. الأمام الثاطبي. (1426هـ=2005م). حرز الأماني ووجه التهاني ضبطه وصححه حمح تميم الزعبي (المجلد

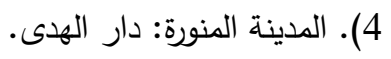

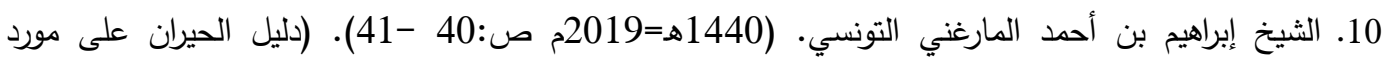
الظمآن في فني الرسم والضبط (الإصدار 40-41، المجلد ط010). تونس، تونس: دار الأمان الرباط.

\section{IJHER}

International Journal of Humanities and Educational Research Volume 2, Issue 4, December 2020, p.19-37 
11. العلامة الثيخ سيدي إبراهيم المارغني. (سنة 1424هـ 2004 م). (النجوم الطوالع على الدرر اللوامع في

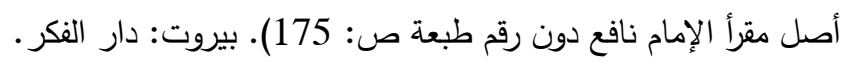

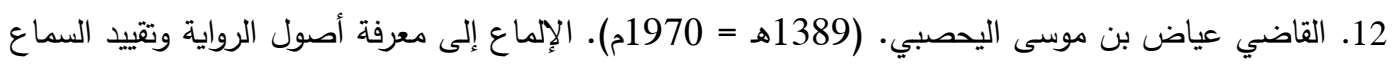
تحقيق السيد أحمد صقر ط01: (المجلد 01). القاهرة وتونس: دار التراث والمكتبة العتيقة. 13. عبد الله بن جعفر بن درستويه النحوي. (1410هـ). رواه الفسوي في المعرفة والتاريخ رواية حققه د أكرم ضياء العمري (الإصدار 377/1، المجلد 01). بالمدينة المنورة: مكتبة الدار.

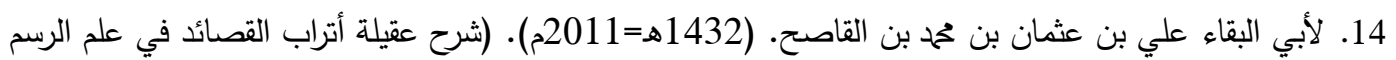
القرآني تحقيق الشيخ محم الدسوقي أمين كحيلة: (المجلد 01). القاهرة: دار السلام للطباعة والنشر . 15. مجد الدين أبو طاهر محمد بن يعقوب الفيروزآبادي. (1426هـ-2005م). (القاموس المحيط تحقيق: مكتب تحقيق التراث في مؤسسة الرسالة بإشراف: محم نعيم العرقُُوسي (المجلد 08). بيروت -لبنان: مؤسسة الرسالة للطباعة والنشر والتوزيع. 